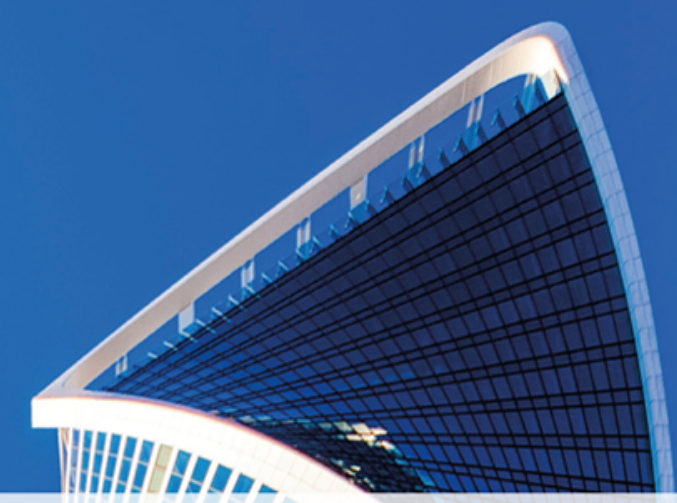

\title{
New Materials
}

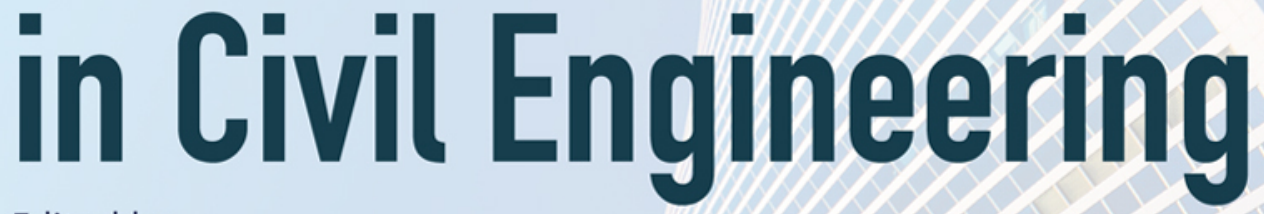

Edited by

Pijush Samui, Dookie Kim, Nagesh R. Iyer and Sandeep Chaudhary

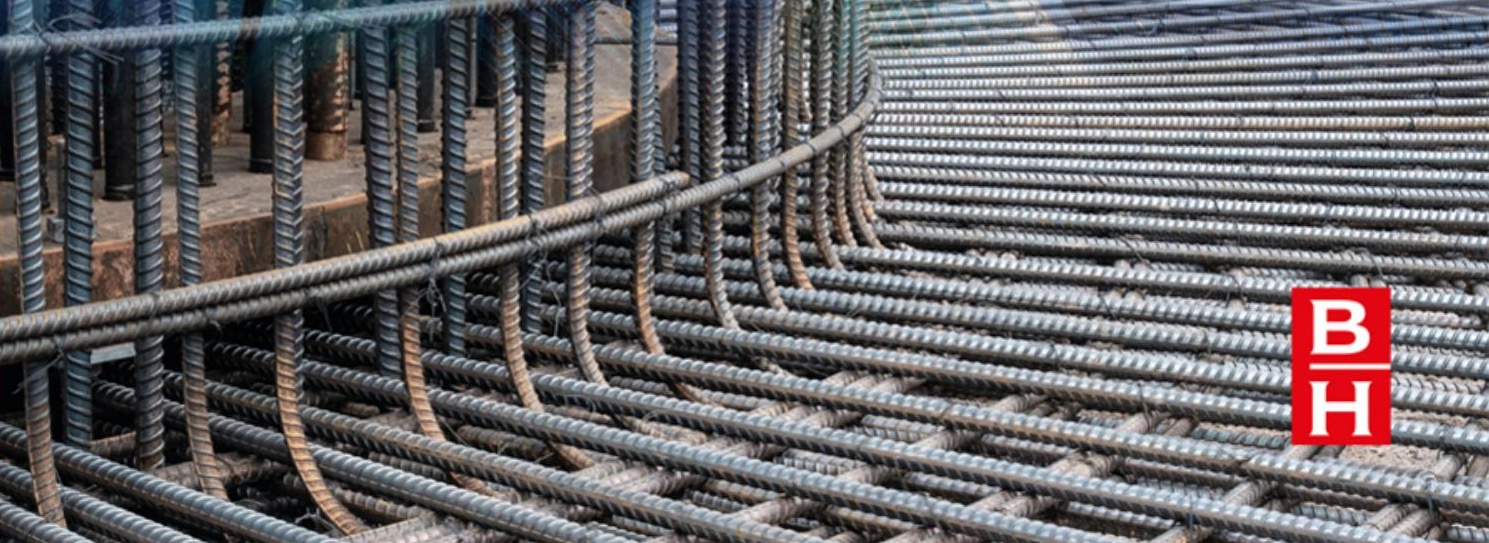


New Materials in Civil Engineering 
This page intentionally left blank 


\section{New Materials in Civil Engineering}

Edited by

\section{Pijush Samui}

Department of Civil Engineering, NIT Patna, Patna, Bihar, India

\section{Dookie Kim}

Department of Civil and Environmental Engineering, Structural System Laboratory, Kongju National University, Cheonan, Chungnam, Republic of Korea

\section{Nagesh R. lyer}

FNAE Dean \& Visiting Professor, Indian Institute of Technology Dharwad, Dharwad, India

\section{Sandeep Chaudhary}

Discipline of Civil Engineering, Indian Institute of Technology Indore, Indore, India
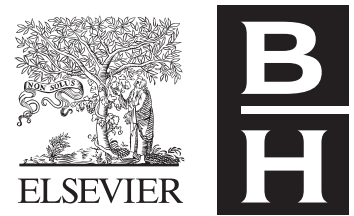
Butterworth-Heinemann is an imprint of Elsevier

The Boulevard, Langford Lane, Kidlington, Oxford OX 5 IGB, United Kingdom 50 Hampshire Street, 5th Floor, Cambridge, MA 02139, United States

Copyright (C) 2020 Elsevier Inc. All rights reserved.

No part of this publication may be reproduced or transmitted in any form or by any means, electronic or mechanical, including photocopying, recording, or any information storage and retrieval system, without permission in writing from the publisher. Details on how to seek permission, further information about the Publisher's permissions policies and our arrangements with organizations such as the Copyright Clearance Center and the Copyright Licensing Agency, can be found at our website: www.elsevier.com/permissions.

This book and the individual contributions contained in it are protected under copyright by the Publisher (other than as may be noted herein).

\section{Notices}

Knowledge and best practice in this field are constantly changing. As new research and experience broaden our understanding, changes in research methods, professional practices, or medical treatment may become necessary.

Practitioners and researchers must always rely on their own experience and knowledge in evaluating and using any information, methods, compounds, or experiments described herein. In using such information or methods they should be mindful of their own safety and the safety of others, including parties for whom they have a professional responsibility.

To the fullest extent of the law, neither the Publisher nor the authors, contributors, or editors, assume any liability for any injury and/or damage to persons or property as a matter of products liability, negligence or otherwise, or from any use or operation of any methods, products, instructions, or ideas contained in the material herein.

\section{British Library Cataloguing-in-Publication Data}

A catalogue record for this book is available from the British Library

\section{Library of Congress Cataloging-in-Publication Data}

A catalog record for this book is available from the Library of Congress

ISBN: 978-0-12-818961-0

For Information on all Butterworth-Heinemann publications visit our website at https://www.elsevier.com/books-and-journals

Publisher: Matthew Deans

Editorial Project Manager: Ana Claudia Garcia

Production Project Manager: Nirmala Arumugam

Cover Designer: Mark Rogers

Typeset by MPS Limited, Chennai, India

Working together to grow libraries in developing countries 


\section{Dedication}

Dedication in memory of my father

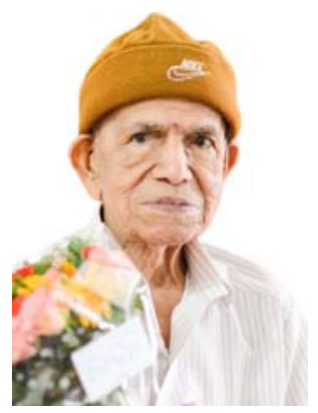

Prof. G.R. Ranganatha Iyer

(June 26, 1922-October 30, 2019)

Chief Engineer \& Joint Secretary (Retd), Govt. of Gujarat Professor of Civil Engineering, L.D. College of Engineering, Gujarat University \& Technical Advisor, World Bank

He has been a fountainhead of knowledge, inspiration, philosophy, and an excellent disciple of spiritual learning; a noble soul radiating love and warmth; he has left behind a rich harvest of memories to cherish, honor, and emulate. He was a magnanimous presence, an endearing soul who spread happiness and love with his brilliant smile and words of encouragement. We pray for his soul and salute him for his foot prints on the sands of time! We will remember him in every moment in every walk of our lives, as we continue to be inspired by him, forever. People of his kind never die! 
This page intentionally left blank 


\section{Contents}

List of Contributors

xvii

1 An overview of cementitious construction materials 1

Nagesh R. Iyer

1.1 Cement and concrete 1

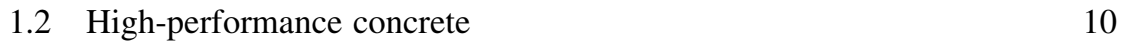

$\begin{array}{ll}1.3 \text { Geopolymer concrete } & 13\end{array}$

$\begin{array}{lll}1.4 & \text { Fiber-reinforced concrete } & 16\end{array}$

1.5 Fiber-reinforced concrete polymer composites 23

$\begin{array}{lll}1.6 & \text { Lightweight concrete } & 25\end{array}$

$\begin{array}{lll}1.7 & \text { Ultrahigh-strength concrete } & 40\end{array}$

$\begin{array}{lll}1.8 & \text { Biomimetics and bacterial concrete } & 50\end{array}$

$\begin{array}{ll}\text { Acknowledgments } & 61\end{array}$

$\begin{array}{ll}\text { References } & 61\end{array}$

2 Computational intelligence for modeling of pavement surface characteristics

Behrouz Mataei, Fereidoon Moghadas Nejad, Hamzeh Zakeri and Amir H. Gandomi

$\begin{array}{lll}2.1 & \text { Introduction } & 65\end{array}$

2.2 Computational intelligence methods 67

$\begin{array}{lll}2.3 \text { Conclusion } & 75\end{array}$

$\begin{array}{ll}\text { References } & 76\end{array}$

$\begin{array}{ll}\text { Further reading } & 77\end{array}$

3 Computational intelligence for modeling of asphalt pavement surface distress

Sajad Ranjbar, Fereidoon Moghadas Nejad, Hamzeh Zakeri

and Amir H. Gandomi

$\begin{array}{lll}3.1 & \text { Introduction } & 79\end{array}$

$\begin{array}{ll}3.2 \text { CI methods } & 80\end{array}$

$\begin{array}{lll}3.3 & \text { Methodology and application } & 84\end{array}$

3.4 Application of CI frameworks in PMS 97

$\begin{array}{ll}3.5 \text { Conclusion } & 102\end{array}$

$\begin{array}{ll}\text { References } & 104\end{array}$ 
4 Expanded polystyrene geofoam

S.N. Moghaddas Tafreshi, S.M. Amin Ghotbi Siabil and A.R. Dawson

4.1 Introduction

4.2 EPS properties

4.3 EPS in embankments

4.4 EPS in bridge abutments and retaining structures 138

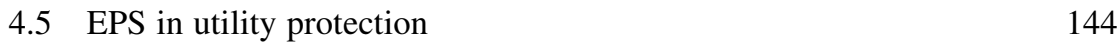

4.6 EPS in other uses 149

$\begin{array}{lll}4.7 \text { Conclusions } & 150\end{array}$

$\begin{array}{lr}\text { References } & 151\end{array}$

5 Recycling of industrial wastes for value-added applications in clay-based ceramic products: a global review (2015-19)

M. Contreras, M.J. Gázquez, M. Romero and J.P. Bolívar

5.1 Introduction

5.2 Industrial waste materials as aggregate in clay ceramics

5.3 Review of studies into the incorporation of waste materials in brick making

$\begin{array}{lll}5.4 & \text { Discussion } & 208\end{array}$

$\begin{array}{ll}\text { References } & 209\end{array}$

6 Emerging advancement of fiber-reinforced polymer composites in structural applications

Kishore Kumar Mahato, Krishna Dutta and Bankim Chandra Ray

6.1 Introduction

6.2 Assessment of fiber-reinforced polymer composites by mechanical, chemical, and thermal behaviors

6.3 Evaluation of special structural properties

6.4 Environmental durability of fiber-reinforced polymer composites in civil structures

$\begin{array}{ll}\text { 6.5 Conclusions and future perspectives } & 261\end{array}$

$\begin{array}{ll}\text { Acknowledgment } & 262\end{array}$

$\begin{array}{ll}\text { References } & 262\end{array}$

7 Fiber-reinforced concrete and ultrahigh-performance fiber-reinforced concrete materials

Francesco Micelli, Angela Renni, Abdou George Kandalaft and Sandro Moro

7.1 Fiber-reinforced concrete

7.2 Ultrahigh-performance concrete ultrahigh-performance fiber-reinforced concrete 
8 The superplasticizer effect on the rheological and mechanical properties of self-compacting concrete

Mouhcine Ben Aicha

8.1 Introduction

8.2 Chemical structure of superplasticizers

8.3 Action mechanisms of superplasticizers

8.4 Superplasticizer effect on cement paste

8.5 Superplasticizer effects on concrete rheology

8.6 Superplasticizer effect on concrete compressive strength

8.7 Conclusion

References

9 Trends and perspectives in the use of timber and derived products in building façades

Anna Sandak, Marcin Brzezicki and Jakub Sandak

9.1 Introduction

9.2 Biobased façade materials

9.3 Trends and perspectives

9.4 Conclusions

Acknowledgment

References

10 Dynamic response of laminated composite plates fitted with piezoelectric actuators

S.K. Sahu, A. Gupta and E.V. Prasad

10.1 Introduction

10.2 Formulation

10.3 Linear static analysis of cross-ply laminated plates

10.4 Dynamic and transient analyses

10.5 Nonlinear vibration analysis of composite plates embedded with piezoelectric materials

10.6 Conclusion

References

11 Functional nanomaterials and their applications toward smart and green buildings

Kwok Wei Shah, Ghasan Fahim Huseien and Teng Xiong

11.1 Introduction

11.2 Sustainability of traditional ordinary Portland cement-based concrete

11.3 Self-healing concrete

11.4 Nanomaterials

11.5 Nanomaterial-based self-healing concrete

11.6 Sustainability of nanomaterial-based self-healing concrete 
11.7 Advantages and disadvantages of nanomaterials for self-healing concrete $\quad 420$

11.8 Economy of nanomaterial-based self-healing concretes 420

11.9 Environmental suitability and safety features of nanomaterial-based concretes

11.10 Conclusions

422

References

423

12 Production of sustainable concrete composites comprising waste metalized plastic fibers and palm oil fuel ash

435

Hossein Mohammadhosseini, Mahmood Md. Tahir,

Rayed Alyousef and Hisham Alabduljabbar

12.1 Introduction

435

12.2 Waste metalized plastic fibers 437

12.3 Concrete incorporating waste metalized plastic fibers 439

12.4 Applications $\quad 454$

12.5 Conclusions 454

References $\quad 455$

13 Alkali-activated concrete systems: a state of art 459

R. Manjunath and Mattur C. Narasimhan

13.1 Introduction 459

13.2 Geopolymers and alkali-activated cementitious systems 460

13.3 Requirements for alkali activation of ground granulated blast furnace slag $\quad 463$

13.4 Alkali-activated slag systems 463

13.5 Effect of dosage and modulus of activator solutions 464

13.6 Workability and strength characteristics of geopolymers and alkali-activated composites $\quad 465$

13.7 Alkali-activated composites with alternative binders 469

13.8 Alkali-activated composites with different activators 471

13.9 Alkali-activated composites with alternative aggregates 472

13.10 Durability studies on alkali-activated composites 473

13.11 Elevated-temperature performance of alkali-activated composites

13.12 Behaviour of alkali-activated composites incorporated with fibers

13.13 Behaviour of rebar-reinforced structural elements made from alkali-activated concrete mixes $\quad 479$

13.14 Summary of alkali-activated composite systems 480

13.15 Future trends for AA composites-research needs 482

References $\quad 482$ 
14 Porous concrete pavement containing nanosilica from black rice husk ash

Ramadhansyah Putra Jaya

14.1 Introduction

493

14.2 Literature review

14.3 Materials

14.4 Experimental plan

501

14.5 Results and discussions

14.6 Conclusions

523

Acknowledgment

523

References

15 Porous alkali-activated materials

Priyadharshini Perumal, Tero Luukkonen, Harisankar Sreenivasan,

Paivo Kinnunen and Mirja Illikainen

15.1 Introduction

15.2 Porous alkali-activated materials

15.3 Characterization of porosity in alkali-activated materials

15.4 Properties of porous alkali-activated materials

15.5 Functional properties and applications

15.6 Conclusions

Acknowledgments

555

References

16 Lightweight cement-based materials

Teresa M. Pique, Federico Giurich, Christian M. Martín, Florencia Spinazzola and Diego G. Manzanal

16.1 Introduction

16.2 Lightweight/low-strength aggregates

16.3 Lightweight/high-strength aggregates

16.4 Extenders

16.5 Outlook and future trends

References

17 Development of alkali-activated binders from sodium silicate powder produced from industrial wastes

Parthiban Kathirvel

17.1 Introduction

17.2 Alternative for Portland cement

17.3 Alkaline activators

17.4 Waste glass

17.5 Silica fume

17.6 Rice husk ash 
$\begin{array}{lll}\text { 17.7 } & \text { Sugarcane bagasse ash } & 602\end{array}$

$\begin{array}{lll}17.8 & \text { Other materials } & 605\end{array}$

$\begin{array}{lll}17.9 & \text { Cost analysis } & 606\end{array}$

$\begin{array}{lll}17.10 & \text { Summary and conclusions } & 609\end{array}$

References $\quad 609$

18 Innovative cement-based materials for environmental protection and restoration

613

Hosam M. Saleh and Samir B. Eskander

$\begin{array}{lll}18.1 & \text { Introduction } & 613\end{array}$

$\begin{array}{ll}\text { 18.2 Innovative cement-based material } & 617\end{array}$

$\begin{array}{lll}18.3 \text { Conclusions } & 636\end{array}$

References $\quad 638$

19 Comparative effects of using recycled CFRP and GFRP

fibers on fresh- and hardened-state properties of self-compacting concretes: a review

643

M. Mastali, Z. Abdollahnejad, A. Dalvand, A. Sattarifard

and Mirja Illikainen

$\begin{array}{lll}19.1 & \text { Introduction } & 643\end{array}$

$\begin{array}{ll}19.2 & \text { Experimental plan }\end{array}$

$\begin{array}{lll}19.3 & \text { Results and discussion } & 647\end{array}$

$\begin{array}{lll}19.4 \text { Analysis } & 650\end{array}$

$\begin{array}{lll}19.5 & \text { Conclusions } & 652\end{array}$

$\begin{array}{ll}\text { References } & 654\end{array}$

20 Corrosion inhibitors for increasing the service life of structures $\quad 657$

B. Bhuvaneshwari, A. Selvaraj and Nagesh R. Iyer

$\begin{array}{lll}20.1 & \text { Introduction } & 657\end{array}$

$\begin{array}{ll}20.2 & \text { What is corrosion? } \\ 20.3 & 658\end{array}$

$\begin{array}{lll}20.3 & \text { Severity of corrosion } & 660\end{array}$

20.4 Concrete corrosion inhibitors $\quad 661$

$\begin{array}{ll}20.5 & \text { Limitation of inhibitors } \\ 20.6 & 663\end{array}$

20.6 Mechanism of inhibition $\quad 664$

20.7 Techniques to assess inhibitor performances 665

20.8 Concrete corrosion assessing techniques 666

20.9 Surface characterization of the metals/rebars after corrosion 668

20.10 Corrosion product analysis techniques 668

20.11 Durability studies of concrete with admixtures 670

$\begin{array}{ll}20.12 \text { Conclusion } & 673\end{array}$

$\begin{array}{ll}\text { Acknowledgments } & 673\end{array}$

$\begin{array}{ll}\text { References } & 673\end{array}$ 
21 Use of fly ash for the development of sustainable construction materials

Sanchit Gupta and Sandeep Chaudhary

21.1 Introduction

21.2 Sustainable development of fly ash utilization

21.3 Characterization of fly ash

21.4 Fly ash applications

21.5 Developments in industrial fly ash applications

21.6 Conclusions

References

22 An innovative and smart road construction material:

thermochromic asphalt binders

Henglong Zhang, Zihao Chen, Chongzheng Zhu

and Chuanwen Wei

22.1 Introduction

22.2 Three-component organic reversible thermochromic materials

22.3 The performance characterization of thermochromic asphalt binders

22.4 The adjustment of bituminous pavement temperature

22.5 Recommendations for future research and applications

23 Resin and steel-reinforced resin used as injection materials in bolted connections

Haohui Xin, Martin Nijgh and Milan Veljkovic

23.1 Introduction

23.2 Computational homogenization

23.3 Experiments

23.4 Numerical simulation of resin

23.5 Numerical simulation of steel-reinforced resin

23.6 Conclusions

References

24 Swelling behavior of expansive soils stabilized with expanded polystyrene geofoam inclusion

S. Selvakumar and B. Soundara

24.1 Effect of geobeads inclusion

24.2 Effect of the geofoam granules column

24.3 Conclusions

Acknowledgments

References 
25 New generation of cement-based composites for civil engineering

Danna Wang, Wei Zhang and Baoguo Han

25.1 Introduction

25.2 Smart and multifunctional cement-based composites 778

25.3 Nanocement-based composites $\quad 784$

25.4 Conclusions $\quad 789$

Acknowledgments $\quad 790$

References $\quad 790$

26 Potential use of recycled aggregate as a self-healing concrete carrier

Chao Liu and Zhenyuan Lv

$\begin{array}{lll}26.1 & \text { Introduction } & 797\end{array}$

26.2 Self-healing concrete materials 802

26.3 Method and results $\quad 805$

26.4 Effect of recycled aggregate in self-healing concrete 817

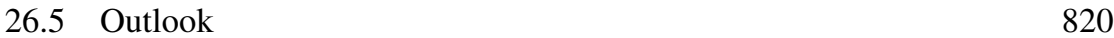

$\begin{array}{ll}\text { References } & 821\end{array}$

27 Self-healing concrete $\quad \mathbf{8 2 5}$

Xu Huang and Sakdirat Kaewunruen

27.2 Materials and methods $\quad 828$

27.3 Results $\quad 835$

27.4 Discussion $\quad 851$

27.5 Conclusion $\quad 853$

$\begin{array}{lr}\text { Acknowledgments } & 854\end{array}$

$\begin{array}{lr}\text { Author contributions } & 854\end{array}$

Conflicts of interest $\quad 854$

References $\quad 854$

28 Equations for prediction of rubberized concrete compressive strength: a literature review

Marijana Hadzima-Nyarko and Ivana Miličević

28.1 Introduction 857

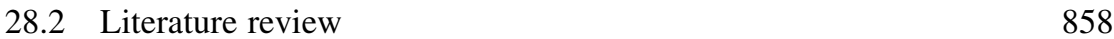

$\begin{array}{lll}28.3 & \text { Database description } & 859\end{array}$

28.4 Expressions for compressive strength in the literature 864

28.5 Expressions for compressive strength of concrete 865

28.6 Comparison of existing expressions 869

$\begin{array}{lll}28.7 & \text { Conclusion } & 872\end{array}$

$\begin{array}{lr}\text { Acknowledgment } & 872\end{array}$

$\begin{array}{lr}\text { References } & 872\end{array}$ 
29 Influence of cobinders on durability and mechanical properties of alkali-activated magnesium aluminosilicate binders from soapstone

Z. Abdollahnejad, M. Mastali, F. Rahim, Tero Luukkonen,

Paivo Kinnunen and Mirja Illikainen

29.1 Introduction

29.2 Experimental plan

29.3 Results and discussion

29.4 Conclusions

892

Acknowledgment

894

References

30 Fly ash utilization in concrete tiles and paver blocks

S.K. Sahu, S. Kamalakkannan and P.K. Pati

30.1 Introduction

30.2 Experimental procedure

900

30.3 Results and discussion

905

30.4 Conclusion

915

References

31 Problems in short-fiber composites and analysis of chopped fiber-reinforced materials

Vahid Monfared

31.1 Introduction

31.2 Analytical methods

31.3 Numerical methods

31.4 Experimental methods

31.5 Constitutive and fundamental researches

31.6 Solved problems

References 
This page intentionally left blank 


\section{List of Contributors}

Z. Abdollahnejad Fibre and Particle Engineering Research Unit, Faculty of Technology, University of Oulu, Oulu, Finland; Civil \& Environmental Engineering Department, University of Connecticut, CT, United States

Hisham Alabduljabbar Department of Civil Engineering, College of Engineering, Prince Sattam bin Abdulaziz University, Alkharj, Saudi Arabia

Rayed Alyousef Department of Civil Engineering, College of Engineering, Prince Sattam bin Abdulaziz University, Alkharj, Saudi Arabia

Mouhcine Ben Aicha National School of Architecture, Rabat, Morocco

B. Bhuvaneshwari Department of Chemical Engineering, Indian Institute of Technology Kanpur, Kanpur, India

J.P. Bolívar Department of Applied Physics, Faculty of Experimental Sciences, University of Huelva, Natural Resources, Health and Environment Research Center (RENSMA), Huelva, Spain

Marcin Brzezicki Wroclaw University of Science and Technology, Faculty of Architecture, Wroclaw, Poland

Sandeep Chaudhary Discipline of Civil Engineering, Indian Institute of Technology Indore, Indore, India

Zihao Chen Key Laboratory for Green \& Advanced Civil Engineering Materials and Application Technology of Hunan Province, College of Civil Engineering, Hunan University, Changsha, P.R. China

M. Contreras Department of Applied Physics, Faculty of Experimental Sciences, University of Huelva, Natural Resources, Health and Environment Research Center (RENSMA), Huelva, Spain

A. Dalvand Department of Engineering, Lorestan University, Khorramabad, Iran

A.R. Dawson Nottingham Transportation Engineering Centre, University of Nottingham, Nottingham, United Kingdom 
Krishna Dutta Composite Materials Laboratory, Department of Metallurgical and Materials Engineering, National Institute of Technology, Rourkela, India

Samir B. Eskander Radioisotope Department, Nuclear Research Center, Atomic Energy Authority, Giza, Egypt

Amir H. Gandomi Faculty of Engineering \& Information Technology, University of Technology Sydney, NSW, Australia

M.J. Gázquez Department of Applied Physics, University of Cadiz, University Marine Research Institute (INMAR), Cádiz, Spain

S.M. Amin Ghotbi Siabil Department of Civil Engineering, K.N. Toosi University of Technology, Tehran, Iran

Federico Giurich Polymers for the Oil and Construction Industry, Engineering Faculty, Universidad de Buenos Aires, Buenos Aires University, Argentina

A. Gupta Department of Civil Engineering, OP Jindal University, Raigarh, Chhattisgarh, India

Sanchit Gupta Discipline of Civil Engineering, Indian Institute of Technology Indore, Indore, India

Marijana Hadzima-Nyarko Josip Juraj Strossmayer University of Osijek, Faculty of Civil Engineering and Architecture Osijek, Osijek, Croatia

Baoguo Han School of Civil Engineering, Dalian University of Technology, Dalian, P.R. China

Xu Huang Department of Civil Engineering, School of Engineering, University of Birmingham, Birmingham, United Kingdom

Ghasan Fahim Huseien Department of Building, School of Design and Environment, National University of Singapore, Singapore

Mirja Illikainen Civil \& Environmental Engineering Department, University of Connecticut, CT, United States; Fibre and Particle Engineering Research Unit, Faculty of Technology, University of Oulu, Oulu, Finland

Nagesh R. Iyer Fellow, Indian National Academy of Engineering, Dean \& Visiting Professor, Indian Institute of Technology, Dharwad, India

Ramadhansyah Putra Jaya Department of Civil Engineering, College of Engineering, University of Malaysia Pahang, Kuantan, Malaysia 
Sakdirat Kaewunruen Laboratory for Track Engineering and Operations for Future Uncertainties (TOFU Lab), School of Engineering, University of Birmingham, Birmingham, United Kingdom

S. Kamalakkannan Department of Civil Engineering, NIT Rourkela, Odisha, India

Abdou George Kandalaft BASF Construction Chemicals, Italy

Parthiban Kathirvel School of Civil Engineering, SASTRA Deemed University, Thanjavur, India

Paivo Kinnunen Fibre and Particle Engineering Research Unit, University of Oulu, Oulu, Finland; Civil \& Environmental Engineering Department, University of Connecticut, CT, United States

Chao Liu Xi'an University of Architecture and Technology, Xi'an, China

Tero Luukkonen Fibre and Particle Engineering Research Unit, University of Oulu, Oulu, Finland; Civil \& Environmental Engineering Department, University of Connecticut, CT, United States

Zhenyuan Lv Xi' an University of Architecture and Technology, Xi'an, China

Kishore Kumar Mahato School of Mechanical Engineering, Vellore Institute of Technology, Vellore, India

R. Manjunath Department of Civil Engineering, National Institute of Technology Karnataka, Surathkal, India

Diego G. Manzanal National Univerity of Patagonia, Comodoro Rivadavia, Argentina; ETS of Roads, Canals and Ports, Polytechnique University of Madrid, Madrid, Spain

Christian M. Martín Polymers for the Oil and Construction Industry, Engineering Faculty, Universidad de Buenos Aires, Buenos Aires University, Argentina

M. Mastali Fibre and Particle Engineering Research Unit, Faculty of Technology, University of Oulu, Oulu, Finland; Civil \& Environmental Engineering Department, University of Connecticut, CT, United States

Behrouz Mataei Department of Civil and Environment Engineering, Amirkabir University of Technology, Tehran, Iran

Francesco Micelli University of Salento, Lecce, Italy 
Ivana Miličević Josip Juraj Strossmayer University of Osijek, Faculty of Civil Engineering and Architecture Osijek, Osijek, Croatia

S.N. Moghaddas Tafreshi Department of Civil Engineering, K.N. Toosi University of Technology, Tehran, Iran

Hossein Mohammadhosseini Institute for Smart Infrastructure and Innovative Construction (ISIIC), School of Civil Engineering, Faculty of Engineering, Universiti Teknologi Malaysia (UTM), Skudai, Johor, Malaysia

Vahid Monfared Department of Mechanical Engineering, Zanjan Branch, Islamic Azad University, Zanjan, Iran

Sandro Moro BASF Construction Chemicals, Italy

Mattur C. Narasimhan Department of Civil Engineering, National Institute of Technology Karnataka, Surathkal, India

Fereidoon Moghadas Nejad Department of Civil and Environment Engineering, Amirkabir University of Technology, Tehran, Iran

Martin Nijgh Faculty of Civil Engineering and Geosciences, Delft University of Technology, Delft, The Netherlands

P.K. Pati Department of Civil Engineering, NIT Rourkela, Odisha, India

Priyadharshini Perumal Fibre and Particle Engineering Research Unit, University of Oulu, Oulu, Finland

Teresa M. Pique Polymers for the Oil and Construction Industry, Engineering Faculty, Universidad de Buenos Aires, Buenos Aires University, Argentina

E.V. Prasad Department of Civil Engineering, OP Jindal University, Raigarh, Chhattisgarh, India

F. Rahim Civil \& Environmental Engineering Department, University of Connecticut, CT, United States

Sajad Ranjbar Department of Civil and Environment Engineering, Amirkabir University of Technology, Tehran, Iran

Bankim Chandra Ray Composite Materials Laboratory, Department of Metallurgical and Materials Engineering, National Institute of Technology, Rourkela, India 
Angela Renni Roughan \& O’Donovan Consulting Engineers, Dublin, Ireland

M. Romero Department of Construction, Eduardo Torroja Institute for Construction Science (IETcc-CSIC), Madrid, Spain

S.K. Sahu Department of Civil Engineering, NIT Rourkela, Odisha, India

Hosam M. Saleh Radioisotope Department, Nuclear Research Center, Atomic Energy Authority, Giza, Egypt

Anna Sandak InnoRenew CoE, Izola, Slovenia; University of Primorska, Faculty of Mathematics, Natural Sciences and Information Technologies, Koper, Slovenia

Jakub Sandak InnoRenew CoE, Izola, Slovenia; University of Primorska, Andrej Marušič Institute, Koper, Slovenia

A. Sattarifard Faculty of Civil Engineering, Semnan University, Semnan, Iran

S. Selvakumar Department of Civil Engineering, Vel Tech Rangarajan Dr. Sagunthala R\&D Institute of Science and Technology, Chennai, India

A. Selvaraj CBM College, Bharathiar University, Coimbatore, India

Kwok Wei Shah Department of Building, School of Design and Environment, National University of Singapore, Singapore

B. Soundara Department of Civil Engineering, Bannari Amman Institute of Technology, Sathyamangalam, Erode, India

Florencia Spinazzola Polymers for the Oil and Construction Industry, Engineering Faculty, Universidad de Buenos Aires, Buenos Aires University, Argentina

Harisankar Sreenivasan Fibre and Particle Engineering Research Unit, University of Oulu, Oulu, Finland

Mahmood Md. Tahir Institute for Smart Infrastructure and Innovative Construction (ISIIC), School of Civil Engineering, Faculty of Engineering, Universiti Teknologi Malaysia (UTM), Skudai, Johor, Malaysia

Milan Veljkovic Faculty of Civil Engineering and Geosciences, Delft University of Technology, Delft, The Netherlands

Danna Wang School of Civil Engineering, Dalian University of Technology, Dalian, P.R. China 
Chuanwen Wei Key Laboratory for Green \& Advanced Civil Engineering Materials and Application Technology of Hunan Province, College of Civil Engineering, Hunan University, Changsha, P.R. China

Haohui Xin Faculty of Civil Engineering and Geosciences, Delft University of Technology, Delft, The Netherlands

Teng Xiong Department of Building, School of Design and Environment, National University of Singapore, Singapore

Hamzeh Zakeri Department of Civil and Environment Engineering, Amirkabir University of Technology, Tehran, Iran

Henglong Zhang Key Laboratory for Green \& Advanced Civil Engineering Materials and Application Technology of Hunan Province, College of Civil Engineering, Hunan University, Changsha, P.R. China

Wei Zhang School of Civil Engineering, Dalian University of Technology, Dalian, P.R. China

Chongzheng Zhu Key Laboratory for Green \& Advanced Civil Engineering Materials and Application Technology of Hunan Province, College of Civil Engineering, Hunan University, Changsha, P.R. China 


\section{Lightweight cement-based materials}

Teresa M. Pique ${ }^{1}$, Federico Giurich ${ }^{1}$, Christian M. Martín ${ }^{1}$,

Florencia Spinazzola ${ }^{1}$ and Diego G. Manzana R, $^{3}$

${ }^{1}$ Polymers for the Oil and Construction Industry, Engineering Faculty, Universidad de

Buenos Aires, Buenos Aires University, Argentina, ${ }^{2}$ National Univerity of Patagonia,

Comodoro Rivadavia, Argentina, ${ }^{3}$ ETS of Roads, Canals and Ports, Polytechnique

University of Madrid, Madrid, Spain

\subsection{Introduction}

Nowadays, different properties are expected for building materials. Durability and high resistance are the common requirements, but every day more applications demand reduced weight as a required property. As a means of reducing environmental impact, sustainable construction requires considering not only the type of materials used, but also the way they affect the building process and the long-term performance of the structure. Lightweight materials are known for their insulating properties, thus low-energy conditioning of housing is one of the main reasons for their use in construction. However, these materials usually have poor mechanical properties. For this reason, lightweight materials are mostly used in nonstructural applications, such as covering mortars for walls, flat roof insulation, or concrete sandwich wall panels. In these cases, different approaches to lower the density of cement-based materials can be considered, such as using lightweight/low-strength aggregates, like expanded polystyrene (EPS), or increasing the water-to-cement ratio.

Despite these approaches that tend to reduce the mechanical properties, it is also possible to reduce the density of a material and maintain a satisfactory strength. For example, cement can be replaced with lightweight/high-strength aggregates such as hollow glass microspheres (HGMSs), which are widely used for oil well lightweight cement slurries. These slurries usually require low density, as the pressure they exert over the formation when pumping it, which directly depends on density, is a limiting variable for its application. Another way to obtain lightweight cementbased materials with acceptable resistance is to enhance the mechanical properties of the binder.

This chapter reviews three techniques for lightening cement-based materials: using EPS, HGMSs, and additives known in the oil well industry as extenders. Both insulating and mechanical properties are specially studied. 


\subsection{Lightweight/low- strength aggregates}

EPS lightweight concrete is one example of cement-based material used in construction. Its production involves partially or fully replacing stone aggregates by EPS particles, depending on the application intended for the concrete. EPS is obtained by the process of expanding atactic polystyrene (PS), an amorphous thermoplastic polymer, whose density is $1050 \mathrm{~kg} / \mathrm{m}^{3}$. Preexpanded atactic PS particles, made of atactic PS mixed with a low boiling point hydrocarbon that serves as a foaming agent, are heated so that the hydrocarbon expands, resulting in an expanded particle around 50 times its original size [1]. Consequently, EPS density is around $10-30 \mathrm{~kg} / \mathrm{m}^{3}$.

Compared to other lightweight aggregates, EPS stands out for being highly porous $(95 \%-98 \%$ of its volume is void space) but at the same time hydrophobic [2]. The latter property makes EPS different from other lightweight aggregates, as it has almost zero absorption of the concrete mixing water [3]. This reduces the needed mixing water but also makes EPS adherence to cement paste more difficult [1], and makes it more prone to segregation as a consequence [4].

Using EPS as concrete aggregate has been the subject of various researches. In most cases, a partial replacement of stone aggregates by EPS particles has been studied. Table 16.1 sums up the relevant features of the analyzed researches.

\subsubsection{Production: fresh state}

Mehta and Monteiro [20] define workability through two properties: consistency and cohesion. Whereas consistency describes the ability of a mixture to flow in the production and casting process, cohesion describes the stability of phases in the mixture, that is, the absence of segregation and bleeding. Both properties must be considered together to achieve a suitable mixture in fresh state, as they are usually affected in opposite ways: when one increases, the other decreases.

In lightweight concretes, segregation due to floating of the lightweight aggregate may happen due to the large difference in densities between the matrix and the aggregate. The main reasons for this are a very low mix cohesion or excessive vibration during compaction [20]. In both cases, low internal friction between aggregates and paste is responsible for segregation: naturally low in the former, vibration-induced in the latter. Vibration makes the mixture less cohesive and allows it to flow toward empty spaces, reducing cavities. However, if vibration is too intense, segregation follows, even in rigid-like mixtures.

EPS lightweight concrete is not exempt from the above-mentioned challenges. Different researches have pointed out aspects that need to be considered during the mix design process and during casting and compacting in order to avoid segregation. Park and Chisholm [11] reported that there is only a slight difference between the water content that makes a mix too cohesive to allow good mixing with EPS particles and the one that makes a mix too fluid to avoid segregation. Similarly, Cook [1] indicated that reducing the water content prevents segregation and stressed 
Table 16.1 Using EPS as concrete aggregate, relevant aspects of analyzed researches.

\begin{tabular}{|c|c|c|c|c|c|c|c|c|}
\hline References & $\begin{array}{l}\text { Type of } \\
\text { cement }\end{array}$ & $\begin{array}{l}\text { Mineral } \\
\text { admixtures }\end{array}$ & $\begin{array}{l}\text { Stone } \\
\text { aggregates }\end{array}$ & $\begin{array}{l}\text { Type of } \\
\text { EPS }\end{array}$ & $\begin{array}{l}\text { EPS } \\
\text { range } \\
\text { (\% vol/ } \\
\text { total } \\
\text { vol) }\end{array}$ & $\begin{array}{l}\text { Density } \\
\text { range } \\
\left(\mathrm{kg} / \mathrm{m}^{3}\right)\end{array}$ & $\begin{array}{l}\text { 28-day } \\
\text { compressive } \\
\text { strength } \\
\text { range (MPa) }\end{array}$ & $\begin{array}{l}\text { Analyzed } \\
\text { properties }\end{array}$ \\
\hline [1] & N/D & - & $\begin{array}{l}\text { Fine and } \\
\text { coarse }\end{array}$ & Spherical beads & $20-70^{\mathrm{a}}$ & - & - & $\begin{array}{l}\text { Mechanical } \\
\text { strength; fresh } \\
\text { state; drying } \\
\text { shrinkage }\end{array}$ \\
\hline [2] & $\begin{array}{l}\text { ASTM } \\
\text { type I }\end{array}$ & 更 & Fine & $\begin{array}{l}\text { Spherical beads } \\
\quad \text { (preexpanded } \\
\text { PS and EPS); } \\
\text { recycled/ } \\
\text { crushed; } \\
\text { recycled/powder }\end{array}$ & $5-35^{\mathrm{a}}$ & $2200-1700$ & $48-17$ & $\begin{array}{l}\text { Mechanical } \\
\text { strength; fresh } \\
\text { state; durability }\end{array}$ \\
\hline [3] & $\begin{array}{l}\text { ASTM } \\
\text { type I }\end{array}$ & Fly ash C & $\begin{array}{r}\text { Fine and } \\
\text { coarse }\end{array}$ & Spherical beads & $16-67$ & $1723-582$ & $12.5-1$ & $\begin{array}{l}\text { Mechanical } \\
\text { strength; } \\
\text { durability }\end{array}$ \\
\hline [5] & $\begin{array}{l}\text { ASTM } \\
\text { type I }\end{array}$ & - & $\begin{array}{l}\text { Fine and } \\
\text { coarse }\end{array}$ & $\begin{array}{l}\text { Recycled/ } \\
\text { thermally } \\
\text { modified }\end{array}$ & $15-60^{\mathrm{a}}$ & $900-2100$ & - & $\begin{array}{l}\text { Fresh state; thermal } \\
\text { conductivity; } \\
\text { drying shrinkage }\end{array}$ \\
\hline [6] & $\begin{array}{l}\text { ASTM } \\
\text { type I }\end{array}$ & Silica fume & $\begin{array}{r}\text { Fine and } \\
\text { coarse }\end{array}$ & Spherical beads & $33-36$ & $1350-1165$ & $11.9-5.6$ & $\begin{array}{l}\text { Mechanical } \\
\text { strength; fresh } \\
\text { state; thermal } \\
\text { conductivity; } \\
\text { drying shrinkage; } \\
\text { durability }\end{array}$ \\
\hline
\end{tabular}

(Continued) 
Table 16.1 (Continued)

\begin{tabular}{|c|c|c|c|c|c|c|c|c|}
\hline References & $\begin{array}{l}\text { Type of } \\
\text { cement }\end{array}$ & $\begin{array}{l}\text { Mineral } \\
\text { admixtures }\end{array}$ & $\begin{array}{l}\text { Stone } \\
\text { aggregates }\end{array}$ & $\begin{array}{l}\text { Type of } \\
\text { EPS }\end{array}$ & $\begin{array}{l}\text { EPS } \\
\text { range } \\
\text { (\% vol/ } \\
\text { total } \\
\text { vol) }\end{array}$ & $\begin{array}{l}\text { Density } \\
\text { range } \\
\left(\mathbf{k g} / \mathbf{m}^{3}\right)\end{array}$ & $\begin{array}{l}\text { 28-day } \\
\text { compressive } \\
\text { strength } \\
\text { range (MPa) }\end{array}$ & $\begin{array}{l}\text { Analyzed } \\
\text { properties }\end{array}$ \\
\hline [7] & $\begin{array}{l}\text { ASTM } \\
\text { type } \\
\text { II }\end{array}$ & - & - & Spherical beads & $38-77^{\mathrm{a}}$ & $1192-464$ & $8.53-0.11$ & $\begin{array}{l}\text { Mechanical } \\
\text { strength; fresh } \\
\text { state }\end{array}$ \\
\hline [8] & $\begin{array}{l}\text { ASTM } \\
\text { type I }\end{array}$ & Silica fume & Fine & Spherical beads & $9-47$ & $1900-1124$ & $30-6.1$ & $\begin{array}{l}\text { Mechanical } \\
\text { strength }\end{array}$ \\
\hline [9] & $\begin{array}{l}\text { ASTM } \\
\text { type I }\end{array}$ & Fly ash C & $\begin{array}{l}\text { Fine and } \\
\text { coarse }\end{array}$ & Spherical beads & $20-50$ & $1858-1012$ & $20-5.5$ & $\begin{array}{l}\text { Mechanical } \\
\text { strength; fresh } \\
\text { state; durability }\end{array}$ \\
\hline [10] & $\begin{array}{l}\text { ASTM } \\
\text { type I }\end{array}$ & $\begin{array}{l}\text { Silica fume, } \\
\text { rice husk } \\
\text { ash }\end{array}$ & $\begin{array}{r}\text { Fine and } \\
\text { coarse }\end{array}$ & Spherical beads & $11-41^{\mathrm{a}}$ & 1900-949 & $35-2.9$ & $\begin{array}{l}\text { Mechanical } \\
\text { strength; drying } \\
\text { shrinkage; } \\
\text { durability }\end{array}$ \\
\hline [11] & $\begin{array}{l}\text { ASTM } \\
\text { type I }\end{array}$ & Fly ash C & Fine & Spherical beads & $53-68^{\mathrm{a}}$ & $1040-520$ & $6.7-0.7$ & $\begin{array}{l}\text { Mechanical } \\
\text { strength; fresh } \\
\text { state; thermal } \\
\text { conductivity; } \\
\text { drying shrinkage }\end{array}$ \\
\hline [12] & $\begin{array}{l}\mathrm{ABCP} \\
\mathrm{CPII}\end{array}$ & 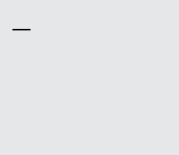 & Fine & Recycled/crushed & $55-65$ & $1250-1110$ & $15.6-8.4$ & $\begin{array}{l}\text { Mechanical } \\
\text { strength; thermal } \\
\text { conductivity; } \\
\text { durability }\end{array}$ \\
\hline [13] & $\begin{array}{l}\text { ASTM } \\
\text { type I }\end{array}$ & $\begin{array}{l}\text { Silica fume, } \\
\text { nanosilica }\end{array}$ & $\begin{array}{r}\text { Fine and } \\
\text { coarse }\end{array}$ & Spherical beads & $7-21^{a}$ & - & - & Fresh state \\
\hline
\end{tabular}




\begin{tabular}{|c|c|c|c|c|c|c|c|c|}
\hline [14] & $\begin{array}{l}\text { ASTM } \\
\text { type I }\end{array}$ & - & $\begin{array}{r}\text { Fine and } \\
\text { coarse }\end{array}$ & Spherical beads & $10-40$ & $1200-2440$ & - & $\begin{array}{l}\text { Thermal } \\
\text { conductivity }\end{array}$ \\
\hline [15] & $\begin{array}{l}\text { ASTM } \\
\text { type I }\end{array}$ & - & Fine & Spherical beads & $36-71$ & $1199-797$ & $6.2-3.1$ & $\begin{array}{l}\text { Mechanical } \\
\text { strength }\end{array}$ \\
\hline [16] & $\begin{array}{l}\text { ASTM } \\
\text { type } \\
\text { IV }\end{array}$ & - & - & Recycled/crushed & $20-80$ & $1567-648$ & $16.9-1.82$ & $\begin{array}{l}\text { Mechanical } \\
\text { strength; thermal } \\
\text { conductivity; } \\
\text { durability }\end{array}$ \\
\hline [17] & $\begin{array}{l}\text { ASTM } \\
\text { type I }\end{array}$ & Nanosilica & - & Spherical beads & $34-36^{\mathrm{a}}$ & $381-584$ & $2.4-0.9$ & $\begin{array}{l}\text { Mechanical } \\
\text { strength; fresh } \\
\text { state; thermal } \\
\text { conductivity }\end{array}$ \\
\hline [18] & $\begin{array}{l}\text { ASTM } \\
\text { type I }\end{array}$ & Nanosilica & - & Spherical beads & $26-44^{\mathrm{a}}$ & - & - & Fresh state \\
\hline [19] & $\begin{array}{l}\text { ASTM } \\
\text { type I }\end{array}$ & Silica fume & $\begin{array}{l}\text { Fine and } \\
\text { coarse }\end{array}$ & Spherical beads & $7-21^{\mathrm{a}}$ & $1712-2235$ & $17-31.5$ & $\begin{array}{l}\text { Mechanical } \\
\text { strength; fresh } \\
\text { state; durability }\end{array}$ \\
\hline [4] & $\begin{array}{l}\text { ASTM } \\
\text { type I }\end{array}$ & Fly ash F & $\begin{array}{r}\text { Fine and } \\
\text { coarse }\end{array}$ & Spherical beads & 0.25 & 2060-2092 & $28-35$ & $\begin{array}{l}\text { Mechanical } \\
\text { strength; fresh } \\
\text { state }\end{array}$ \\
\hline
\end{tabular}

${ }^{\mathrm{a}}$ Values have been estimated through the proposed dosages. 
the importance of using an adherence-improving additive. Sri Ravindrarajah and Tuck [6] reported good cohesion in mixtures made with surface-treated EPS beads to improve adherence.

Kan and Demirboga [7] highlighted that a relatively uniform lightweight concrete can be achieved if vibration is limited to prevent EPS particles from moving toward the top of the mold. Giurich and Pique [18] stated that the amount of vibration needed to achieve a nonsegregated, well-finished EPS concrete member is directly related to the mixture consistency: the higher the consistency, the less the vibration that is needed.

The consistency of EPS lightweight concrete generally decreases with an increase in the EPS content $[2,5,7,12,18]$. This phenomenon is mainly attributed to a lower weight of the mix itself, as weight is the driving force that causes slump. As the mix weight is reduced, lower slump values are obtained. In the case of concrete made purely with EPS particles as aggregates, consistency is also reduced due to the fact that the higher the EPS content, the lower the free cement paste (not adhered to the surface of particles), which is responsible for making the mix flow as a whole [18]. However, in the case of self-compacting EPS concrete, Ranjbar and Mousavi [19] reported that replacing stone aggregates by EPS yields increasing flow values, due to the lower internal friction caused by EPS particles in the mix compared to that caused by stone aggregates.

Madandoust et al. [13] showed that, for a given EPS content, reducing the waterto-cement ratio reduces consistency, due to a decrease in the cement paste viscosity. García-Alcocel and Ferrándiz-Mas [2] reported that for the same EPS content and water-to-cement ratio, consistency of mixtures made with spherical EPS beads is higher than that of mixtures made with crushed recycled EPS. This is because the former has a lower surface area than the latter, thus reducing the surface area to which cement paste adheres and increasing the free cement paste responsible for the mixture flow.

Many researchers have warned about the difficulty of casting and compacting EPS concrete due to its usually rigid-like and sticky consistency [5,6,11]. Kan and Demirboga [7] reported larger compaction efforts associated with a reduction in consistency when the EPS volume is increased. Giurich and Pique [18] added that vibration is not effective in reducing cavities in low-consistency, high-cohesive mixtures, only leading to an increase in segregation. Sri Ravindrarajah and Tuck [6] recommend the usage of plasticizers in mixtures with low water-to-cement ratio in order to reduce the number of cavities, in agreement with other authors [2,7]. Airentraining agents can also be used to improve the workability of EPS concrete; however, the arising reduction of mechanical strength must be considered.

Madandoust et al. [13] proposed developing a self-compacting concrete as a global solution to the issues involving the workability of EPS concrete. The goal is to achieve a naturally nonsegregating mixture that is fluid enough to allow its casting without the need for vibration, which is another source of segregation. To prevent EPS from floating, they recommend increasing the viscosity of mixtures by reducing the water-to-cement ratio or by incorporating mineral admixtures with high specific surface area, such as silica fume or nanosilica. 
Giurich and Piqué [18] reported an increase in cohesion and a reduction in consistency when nanosilica was added to EPS lightweight concrete. For a given water content, increasing the fines means increasing the surface area to which water molecules adsorb, therefore reducing both the amount of free water and the distance between particles. Consequently, there is higher internal friction between particles, which leads to a higher viscosity and a lower consistency of the mixture. This is especially true when nano-sized particles such as nanosilica are added to concrete, even in small quantities, due to the fact that nanoparticles have a specific surface area three orders of magnitude higher than that of ordinary Portland cement. For this reason, an adequate amount of plasticizer is recommended along with the usage of nanosilica in EPS lightweight concrete, in order to achieve both satisfactory cohesion to avoid segregation and satisfactory consistency to allow proper casting [18].

$\mathrm{Li}$ et al. [4] also suggest the usage of viscosity-modifying agents to reduce segregation. These agents act in the same way as high specific surface area admixtures, promoting the adsorption of water molecules on their surface and therefore reducing the content of free water. However, they claim that although stability of the mixture is enhanced, consistency is reduced, which affects negatively the achievement of a self-compacting concrete. For this reason, an adequate balance between cohesion and consistency must be reached through an adequate proportion between a viscosity-modifying agent and a plasticizer.

Both Li et al. [4] and Giurich and Piqué [18] performed similar evaluations of segregation of EPS concrete by producing specimens and then cutting them into equal slices from top to bottom in order to measure the density of each slice. With increasing content of the viscosity-modifying agent in the case of $\mathrm{Li}$ et al. [4] and nanosilica in the case of Giurich and Piqué [18], densities of slices of each specimen became more homogeneous, meaning that segregation was effectively reduced.

\subsubsection{Hardened state properties}

All studies report a decreasing density of concrete as EPS volume increases, because EPS has a density of approximately $10-30 \mathrm{~kg} / \mathrm{m}^{3}$. Fig. 16.1 , made with 66

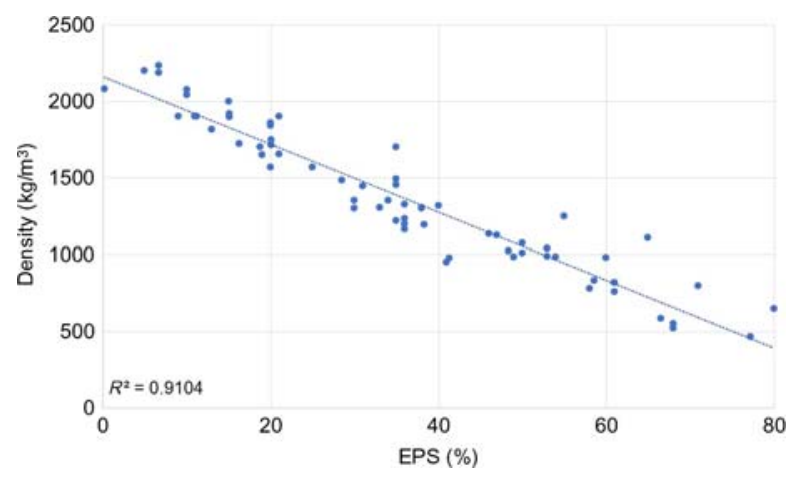

Figure 16.1 Density change with EPS volume change, results from researches in Table 16.1. 
results obtained from 13 different studies [2-4,6-12,15,16,19], shows that density is linearly related to EPS volume in a wide range of densities.

When it comes to strength, EPS particles can be considered as a macropore in concrete, as EPS has a negligible elastic modulus compared to that of the matrix [1]. This means that given a deformation in an EPS lightweight concrete member, the resistance borne by a deformed EPS particle is almost zero due to its low modulus. Stone aggregates, usually having a higher modulus than that of the matrix, work the other way, bearing resistance to deformation and thus increasing the overall strength of concrete. Therefore the strength of EPS lightweight concrete will be provided exclusively by the resistance offered by the rigid components, that is, the cement paste and the stone aggregates when they are present.

Fig. 16.2, made with 65 results from 12 studies [2,3,6-12,15,16,19], shows a reduction of compression strength as EPS volume increases. These compression strength values have also been graphed against density in Fig. 16.3, showing an increase in strength as density increases. The dispersion of dots observed in both figures can be explained by the different materials and dosages used in each study,

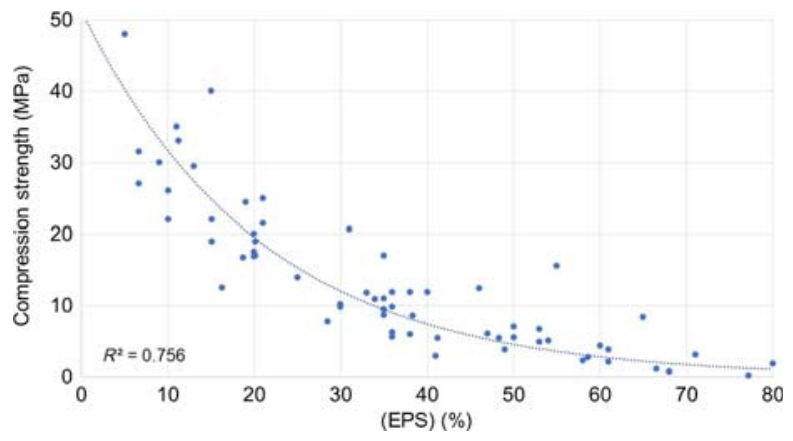

Figure 16.2 Compressive strength change with EPS volume change, results from researches in Table 16.1.

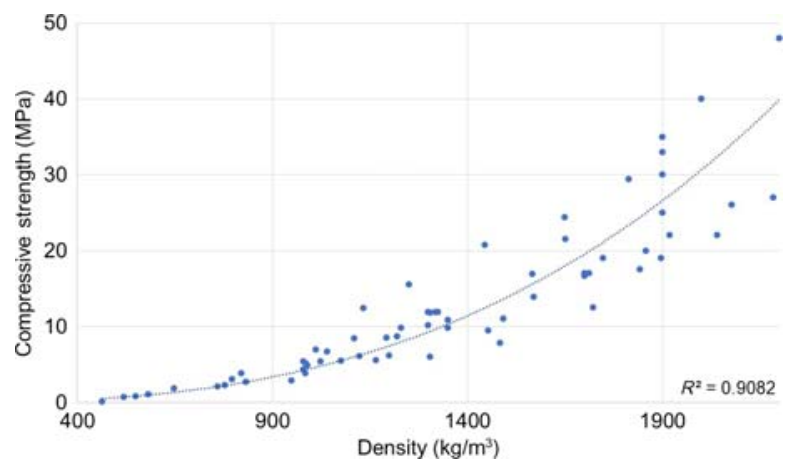

Figure 16.3 Compressive strength change with density change, results from researches in Table 16.1. 
which play an important role in the qualities of the interfacial zone and the matrix. Therefore if measures are taken to improve those qualities, it is possible to partially counteract the strength loss product of EPS inclusion $[13,17]$.

Reducing the overall porosity of cement paste results in an improvement of its mechanical properties. Capillary pores can be reduced by lowering the water-tocement ratio and can be refined with mineral admixtures. Intentionally air-entrained bubbles should be avoided, especially if they are not needed due to durability reasons.

The water-to-cement ratio determines the distance between cement particles and therefore the degree of contact reached by hydration products, which has a key impact on strength [20]. Several authors recommend keeping the water-to-cement ratio as low as possible in EPS concrete so as to avoid further strength loss [1,6,10,17].

Pozzolanic mineral admixtures help transform part of the hydration products with low specific surface area, such as calcium hydroxide crystals, into high specific surface hydration products, thus increasing the contact between solids and the overall strength [20]. The effectiveness of pozzolanic admixtures depends on the amount of noncrystalline silica contained, which determines the extra amount of high specific surface products formed, and on the specific surface area, which determines the reaction velocity.

For pozzolanic reactions to occur, an alkali-rich pore solution is required [21]. At early ages, the presence of sulfate ions in pore solution prevents these reactions from happening. Pozzolanic admixtures, however, prompt changes in the hydration kinetics of cement by showing filler effects. On one hand, they act as nucleation sites, promoting a faster precipitation of clinker hydration products; on the other hand, they provide extra space for those products, as the volume of pozzolanic admixtures remains unchanged while they show filler effects [21]. Once dissolved sulfate ions have reacted with aluminates to form hydration products, the alkalinity in the pore solution grows, and thus, pozzolanic admixtures start to react, leading to a reduction in the content of calcium hydrates and an increase in an additional phase of $\mathrm{C}-\mathrm{S}-\mathrm{H}$.

Chen and Liu [22] studied the influence of fly ash and silica fume on the strength of an expanded clay lightweight concrete. At a given constant binder content, replacements of cement by fly ash and silica fume were carried out. The former has $54.9 \%$ of $\mathrm{SiO}_{2}$ with a specific surface area of $4500 \mathrm{~cm}^{2} / \mathrm{g}$, whereas the latter has $92.4 \%$ of $\mathrm{SiO}_{2}$ with a specific surface area of $18,000 \mathrm{~cm}^{2} / \mathrm{g}$. For a $10 \%$ cement replacement, results for 28-day compression strength show a 5\% increase for the fly ash mix and a $17 \%$ increase for the silica fume mix. Both admixtures enhance the mix strength; however, the higher increase in the silica fume mix is directly related to its higher content of noncrystalline silica. For the same cement replacement, results for 7-day compression strength show an $11 \%$ decrease for the fly ash mix and a $14 \%$ increase for the silica fume mix. This difference in outcome at an early age is related to the reaction velocity, which is faster in the silica fume mix as it has a higher surface area than fly ash.

Sadrmomtazi et al. [10] found that replacing cement by $10 \%$ silica fume in EPS lightweight concretes led to 28-day strength increases ranging from $4 \%$ to $46 \%$ in concretes with 10\%-30\% volume EPS. Giurich and Piqué [18] reported that the 
incorporation of nanosilica also led to a strength increase of EPS lightweight concrete, in agreement with other researches carried out on the incorporation of nanosilica to concrete [23]. They also remarked that segregation should be avoided by all means if a maximization of EPS lightweight concrete strength is desired.

When segregation occurs, EPS tends to accumulate on the top layer of the cast element, creating a weak layer that reaches failure earlier than the bottom layer with low EPS content and therefore reducing the overall strength of the whole. Li et al. [4] studied the influence of segregation on strength by casting cubic specimens of a concrete with $0.25 \%$ volume of EPS and varying degrees of segregation. When compression tests were performed loading specimens on directions both perpendicular and parallel to the casting direction, they found a growing difference between both strengths as segregation increased. Giurich [24] analyzed the impact of segregation on strength using a finite element model representing the compression test of cylindrical specimens of EPS concrete with constant EPS volume. The model yielded results congruent to the experimental results: as segregation increased, the weak layer containing a high volume of EPS was larger and caused the specimen to fail at lower loads. Therefore producing a material that is homogeneous throughout the cast element will lead also to homogeneous and enhanced mechanical properties.

Nanosilica not only benefits EPS concrete strength through the promotion of pozzolanic reactions and through a reduction in segregation, but also through a reduction in porosity that is caused by additives that show an air-entraining secondary effect [24]. Air-entrained bubbles affect negatively the strength of EPS lightweight concretes: Yu et al. [25] reported a 33\% strength loss when an air-entraining agent is used in a recycled glass lightweight concrete; similarly, García-Alcocel and Ferrándiz-Mas [2] reported a 30\% strength loss when this additive was used.

As opposed to strength, thermal conductivity benefits from an increase in both the EPS and air bubble contents. Many studies report a reduction in thermal conductivity as the EPS content increases, or equally, as density decreases $[6,7,14,16,18]$. The reason for this is that EPS has a thermal conductivity of $0.041 \mathrm{~W} / \mathrm{m} \mathrm{K}$ [14], which is much lower than that of stone aggregates typically used in normal-density concretes $(1.6-3.7 \mathrm{~W} / \mathrm{m} \mathrm{K})$. This reduction in EPS lightweight concrete can be further increased when air-entraining agents are used. Kaya and Kar [16] studied the influence of tragacanth resin in EPS lightweight concrete, a natural resin known for increasing the microporosity of concrete. They found that at the same EPS volume, concretes with this resin had lower thermal conductivities. Giurich [24] explained that differences in thermal conductivity values at the same concrete density are probably related to the volume of both EPS and air, with it being lower in concretes with a higher air content. This is due to the fact that air has a thermal conductivity of $0.024 \mathrm{~W} / \mathrm{m} \mathrm{K}$, about half of that of EPS.

In brief, EPS concrete is a versatile material whose properties are as much related to the content of EPS itself as they are to the interactions with the rest of the mix components; as long as a proper workability in fresh state is achieved, a wide variety of mixes with different densities, strengths, and thermal conductivities in the hardened state can be obtained. 


\subsection{Lightweight/high-strength aggregates}

Another alternative for reducing the density of materials in civil engineering consists of the addition of HGMSs. HGMSs have very low densities that range from 100 to $800 \mathrm{~kg} / \mathrm{m}^{3}$. The main difference between these and traditional lightweight additions or aggregates is their high crush strength. This property defines the greatest compressive strength that a brittle material can bear without rupture. Usual lowweight materials used to reduce the density of cement-based materials tend to have low crush strength, resulting in low compressive strength of the composite, whereas HGMSs behave differently due to their higher crush strength. HGMSs have a crush strength that goes from 20 to $186 \mathrm{MPa}$, meaning that they can be added in composite materials in order to obtain low densities without severely affecting their mechanical properties [26].

HGMSs have the appearance of a white powder in a macro scale. They are manufactured from soda-lime borosilicate glass, with $\mathrm{SiO}_{2}$ being its principal component $(60 \%-87 \%)$ [27]. Particle size varies between 20 and $70 \mu \mathrm{m}$. As shown in Fig. 16.4, there is a dependency between this property and their crush strength. HGMS classes are defined by this last property. The relationship between crush strength, particle size, and density is also notable. As is expected, the crush strength decreases with increasing particle size and increases with density. In addition to their low density and high crush strength, HGMSs have good chemical resistance and are stable at temperatures up to $600^{\circ} \mathrm{C}$, depending on the duration of exposure. Because of the properties presented, HGMSs can be used both as insulation agents and as andition in cement pastes for cementing oil wells.

\subsubsection{Hollow glass microspheres as insulation agents}

Many researchers have studied the influence of HGMSs as insulation agents when added to composite materials. HGMSs are not only used in cement-based materials but also in polymeric materials, which demonstrate the versatility of these additions. Moreover, they can be added in a wide range of percentages to obtain composite materials with the desired final properties. The main properties to be considered when analyzing their application are density, strength, thermal conductivity, and
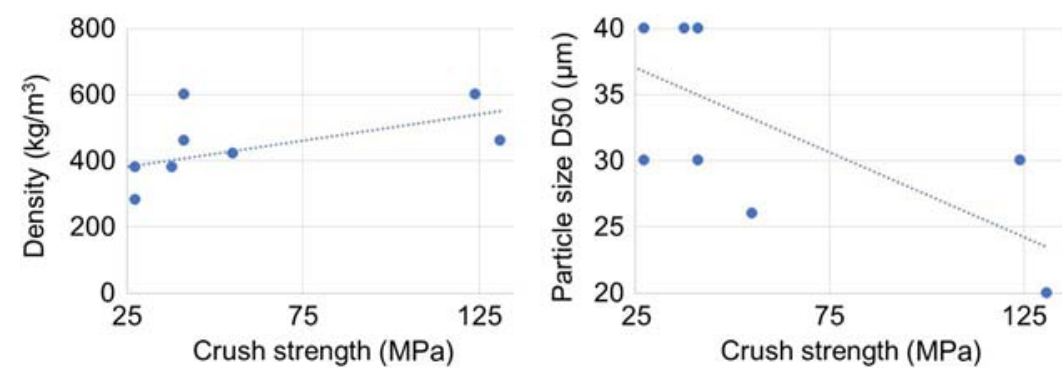

Figure 16.4 Density and particle size of different classes of commercial HGMSs. 
heat resistance. The results obtained by different authors for polymeric and cementbased materials with addition of HGMSs are presented in Table 16.2.

Given the variability in the parameters analyzed by the different researches presents in Table 16.2, in order to achieve a comparative analysis, results are expressed as percentual variations in Figs. 16.5 and 16.6. For all reported researches, it can be noticed that there is a significant reduction in the density of the composites when HGMSs are added (Fig. 16.5). Polymeric composites [29] showed lower density reduction with increasing content of HGMSs when compared to cement-based materials [30-32]. This difference could be attributed principally to the higher density of Portland cement.

Furthermore, either for the shear or compressive strength, there exists a correlation between the decreased density and final strength when adding HGMSs, no matter the type of binder used. Generally, as for other low-strength addition or aggregates, a reduction in the density of the composite material means a reduction

Table 16.2 Using HGMS as insulating agents. Relevant aspects of analyzed researches.

\begin{tabular}{|c|c|c|c|c|c|}
\hline & & HGMS & Density & $\begin{array}{l}\text { Compressive } \\
\text { strength }\end{array}$ & $\begin{array}{l}\text { Thermal } \\
\text { conductivity }\end{array}$ \\
\hline References & Binder & $\begin{array}{l}\text { (mass ratio } \\
\% \text { ) }\end{array}$ & $\left(\mathrm{kg} / \mathrm{m}^{3}\right)$ & (MPa) & $(\mathbf{W} / \mathbf{m} \mathbf{K})$ \\
\hline [28] & $\begin{array}{l}\text { Urethane } \\
\text { acrylate }\end{array}$ & $\begin{array}{l}0 \\
2 \\
5 \\
10\end{array}$ & $\begin{array}{r}1159 \\
1056 \\
921 \\
752\end{array}$ & $\begin{array}{l}- \\
- \\
- \\
-\end{array}$ & $\begin{array}{l}0.230 \\
0.210 \\
0.185 \\
0.160\end{array}$ \\
\hline [29] & $\begin{array}{l}\text { Phenolic } \\
\text { resin }\end{array}$ & $\begin{array}{l}77 \\
83 \\
91 \\
100 \\
111 \\
125 \\
143\end{array}$ & $\begin{array}{l}400 \\
390 \\
370 \\
340 \\
330 \\
310 \\
300\end{array}$ & $\begin{array}{r}14.5 \\
13.7 \\
10.5 \\
9.4 \\
9.0 \\
7.1 \\
6.8\end{array}$ & $\begin{array}{l}0.103 \\
0.101 \\
0.088 \\
0.086 \\
0.085 \\
0.079 \\
0.073\end{array}$ \\
\hline [30] & $\begin{array}{l}\text { Portland } \\
\text { cement }\end{array}$ & $\begin{array}{l}0(w / c 0.55) \\
3(w / c 0.55) \\
6(w / c 0.55) \\
9(w / c 0.55)\end{array}$ & $\begin{array}{l}983 \\
930 \\
906 \\
836\end{array}$ & $\begin{array}{l}1.8 \\
2.2 \\
2.0 \\
1.7\end{array}$ & $\begin{array}{l}0.251 \\
0.260 \\
0.203 \\
-\end{array}$ \\
\hline [31] & $\begin{array}{l}\text { Portland } \\
\text { cement }\end{array}$ & $\begin{array}{l}15 \text { (w/c } 0.40) \\
30 \text { (w/c } 0.67)\end{array}$ & $\begin{array}{l}993 \\
660\end{array}$ & $\begin{array}{l}25.9 \\
13.9\end{array}$ & $\begin{array}{l}0.240 \\
0.160\end{array}$ \\
\hline [32] & $\begin{array}{l}\text { Portland } \\
\text { cement }\end{array}$ & $\begin{array}{l}25 \text { (w/c } 1.40) \\
30 \text { (w/c } 1.40) \\
35 \text { (w/c } 1.40) \\
40 \text { (w/c } 1.40) \\
45 \text { (w/c } 1.40) \\
50 \text { (w/c } 1.40) \\
55 \text { (w/c } 1.40)\end{array}$ & $\begin{array}{l}675 \\
615 \\
540 \\
465 \\
390 \\
345 \\
305\end{array}$ & $\begin{array}{l}2.8 \\
2.4 \\
1.8 \\
1.3 \\
0.8 \\
0.5 \\
0.3\end{array}$ & $\begin{array}{l}0.1370 \\
0.1220 \\
0.1060 \\
0.0940 \\
0.0800 \\
0.0730 \\
0.0680\end{array}$ \\
\hline
\end{tabular}




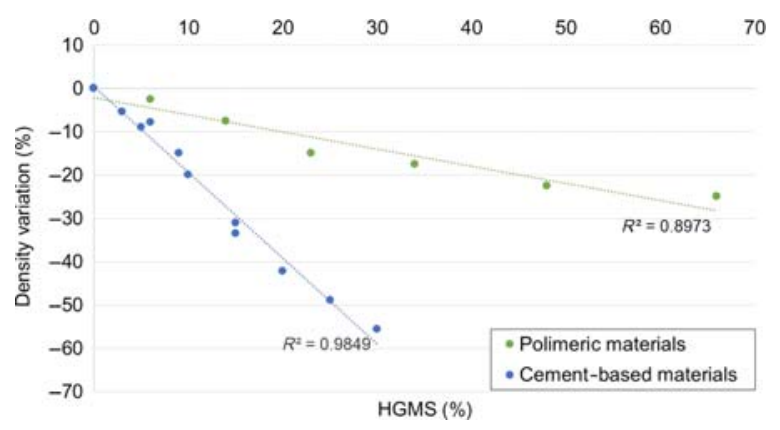

Figure 16.5 Density variation of composite and cement-based materials with the addition of HGMSs. Results correspond to researches in Table 16.2.

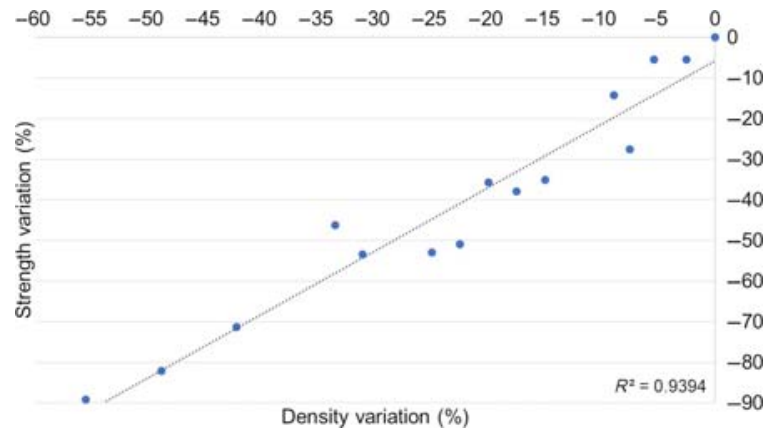

Figure 16.6 Strength variation of polymeric composite and cement-based materials with the reduction of its density due to the addition of HGMSs. Results correspond to researches in Table 16.2.

in its final strength (Fig. 16.6). Regardless of the binding material, it can be appreciated that the behavior of all composites studied is practically identical, showing a linear correlation between density and strength. As was expected, thermal conductivity of both, polymer composites and cement-based materials, decreased with the density of the material (Fig. 16.7).

From the above-presented results, there is a plausible application of HGMSs as an innovating insulation agent regardless of the composite binder. Composites with HGMSs have outstanding thermal conductivity behavior in addition to their low density. When studying the mechanical properties of these materials, it can be outlined that it is not severely affected, especially when compared to other lightweight additions.

\subsubsection{Hollow glass microspheres for oil well cements}

HGMSs are used in oil well cements due to their low density and high crush strength, in order to substantially reduce the specific weight of cement slurries without compromising their final performance. In oil wells, cement slurry is placed 


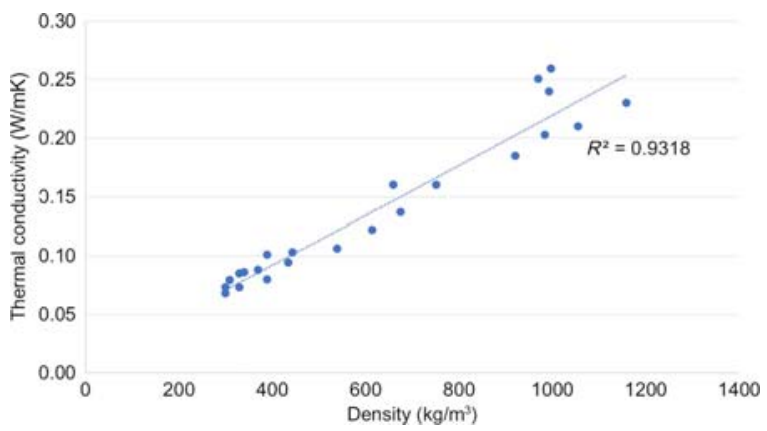

Figure 16.7 Thermal conductivity change with density change. Results from researches in Table 16.2.

between the drilled formation and the casing. Its main objective is to provide zonal isolation in the well. Therefore a hydraulic seal must be generated between the casing and the cement, and between the cement and the formation, while avoiding the generation of channels within the cement slurry. HGMS are used, for example, when boreholes go through weak formations. These cannot withstand the high hydrostatic pressures exerted by normal weight cement slurries when pumped, as their fracture gradient is low. Therefore, lightweight cement slurries are needed, with this being one of their most common applications.

The first reported field application of HGMSs in the oil production industry dates to 1980 when it was intended to overcome the low fracture gradient on an off-shore well in the Gulf of Mexico [33]. Two cementing jobs were accomplished using a slurry with the addition of $27 \%$ by weight of cement of HGMS. The first operation consisted of cementing a $183 \mathrm{~m}$ high annular zone of 61 and $86 \mathrm{~cm}$ casing and hole diameters, respectively. The second operation consisted of a $305 \mathrm{~m}$ high annular zone, 41 and $66 \mathrm{~cm}$ casing and hole diameters, respectively. This case showed that, despite the elevated cost of HGMSs, a substantial improvement in final properties can be obtained by their usage. Densities of $1115 \mathrm{~kg} / \mathrm{m}^{3}$ and better mechanical properties than usual lightweight cement slurries were obtained. Given this result, many researches took place in the petroleum industry to study and apply cement slurries with different classes and percentages of HGMS. Some of these researches are presented in Table 16.3.

It is interesting to note that incorporating HGMSs into oil well cement slurries has significant benefits when compared to incorporating commonly used extenders in the oil well industry to lighten the slurries. For example, when using foamed cements, the densities obtained may be as low as those obtained with the addition of HGMSs, but other properties are severely affected. In this aspect, for the same target densities, a foamed cement slurry will have lower compressive strength and greater porosity than a cement slurry with HGMSs [26]. It is important to highlight that, given the need for an impermeable cement sheath, durability and resistance are fundamental. The strengths obtained with the addition of HGMSs are generally high enough to meet target requirements. 
Table 16.3 Using HGMS in oil well cement slurries, relevant aspects of analyzed researches.

\begin{tabular}{|c|c|c|c|c|c|}
\hline \multirow[b]{2}{*}{ References } & $\begin{array}{l}\text { HGMS crush } \\
\text { resistance }\end{array}$ & $\begin{array}{l}\text { Addition } \\
\text { proportion }\end{array}$ & $\begin{array}{l}\text { Slurry } \\
\text { density }\end{array}$ & $\begin{array}{l}\text { Compressive } \\
\text { strength }\end{array}$ & \multirow[b]{2}{*}{$\begin{array}{l}\text { Other } \\
\text { properties } \\
\text { studied }\end{array}$} \\
\hline & $(\mathrm{MPa}) /\left(\mathrm{kg} / \mathrm{m}^{3}\right)$ & $\begin{array}{l}\text { (mass } \\
\text { ratio \%) }\end{array}$ & $\left(\mathrm{g} / \mathrm{cm}^{3}\right)$ & (MPa) & \\
\hline [34] & 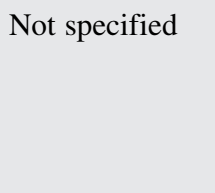 & $\begin{array}{r}0 \\
3 \\
12 \\
18 \\
20\end{array}$ & $\begin{array}{l}1.74 \\
1.62 \\
1.56 \\
1.50 \\
1.50\end{array}$ & $\begin{array}{r}33.3 \\
17.9 \\
20.2 \\
2.0 \\
17.3\end{array}$ & - \\
\hline [35] & Not specified & 18 & 1.32 & 9.7 & $\begin{array}{l}\text { Thickening } \\
\text { time test } \\
\text { and HGMS } \\
\text { segregation }\end{array}$ \\
\hline [36] & $\begin{array}{l}27.6 / 380 \\
55.2 / 420 \\
131.0 / 460 \\
41.4 / 600\end{array}$ & $\begin{array}{l}10.43 \\
12.41 \\
14.82 \\
17.67 \\
11.86 \\
14.16 \\
16.92 \\
20.19 \\
13.31 \\
16.02 \\
19.15 \\
22.98 \\
19.28\end{array}$ & $\begin{array}{l}1.463 \\
1.401 \\
1.340 \\
1.278 \\
1.454 \\
1.393 \\
1.329 \\
1.260 \\
1.462 \\
1.401 \\
1.340 \\
1.278 \\
1.462\end{array}$ & $\begin{array}{r}11.4 \\
9.5 \\
6.4 \\
5.3 \\
10.4 \\
9.2 \\
6.8 \\
5.1 \\
9.1 \\
7.0 \\
5.7 \\
4.2 \\
8.1\end{array}$ & $\begin{array}{l}\text { Slurry density } \\
\text { variation } \\
\text { with } \\
\text { pressure }\end{array}$ \\
\hline
\end{tabular}

Generally, in oil well applications, the proportion of HGMSs is selected in order to achieve a target cement slurry density. This is chosen in accordance with the maximum specific weight acceptable for the lowest fracture strength of the drilled formation. As can be noted in Table 16.3, this proportion differs from one class of HGMSs to another due to the difference in their specific weight. Regarding this last issue, Mata and Calubayan [36] analyzed the relation between density, cement replacement percentage, HGMS crush strength (or class) and compressive strength of the cement slurries. They kept constant the water-to-cement ratio and four target densities were fixed: $1260,1320,1380$, and $1440 \mathrm{~kg} / \mathrm{m}^{3}$. These densities were achieved by replacing cement in different percentages. The results of the compressive strength for each target density obtained with different classes of HGMSs are shown in Fig. 16.8. 


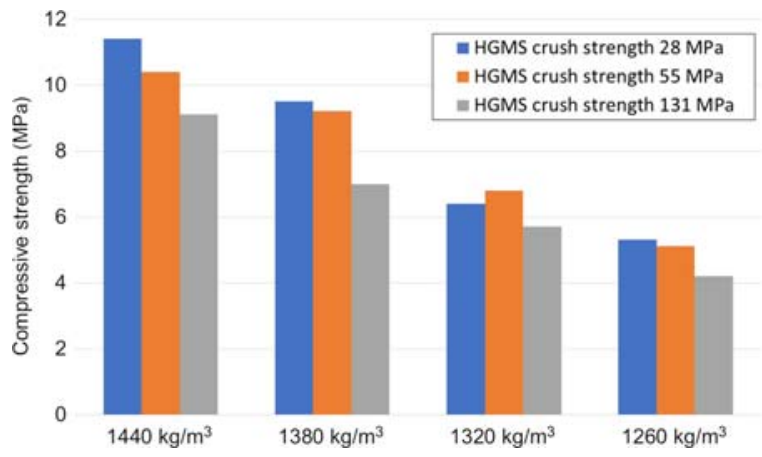

Figure 16.8 Compressive strength of targeted densities for lightweight cement slurries designed with HGMSs with different crush strengths.

Source: Adapted from C. Mata, A. Calubayan, Use of hollow glass spheres in lightweight cements - selection criteria, in: Proceeding of Engineers Asia Pacific Oil and Gas Conference and Exhibition SPE-182399-MS, Perth, Australia, October 25-27, 2016.

It can be observed that the final strength for the target densities varies with the class of HGMS. This can be explained by the fact that different classes of HGMS have different densities. It is interesting to notice that the HGMS class with the highest compressive strength is not the one that yields the highest compressive strength for a targeted density of a lightweight oil well cement slurry.

AlBahrani et al. [37] prepared a specially designed experimental procedure to analyze the performance of different classes of HGMS under oil well conditions. HGMSs were subjected to an aging process that simulates the high-pressure and high-temperature conditions in an oil well and the impact forces generated during the cement slurry mixing and pumping into the formation. No clear relation between HGMS crush strength and aging resistance was found in this case. Given these results, the selection criteria of HGMSs is key when designing a lightweight cement slurry since no clear laws govern their behavior. Despite this difficulty, researches show that there is a great range of applications for this material, especially when considering the low densities and relatively high compressive strengths obtained by its use in the oil well industry.

\subsection{Extenders}

In addition to the HGMSs, the oil well industry uses a wide range of density reducer additives or density reducer admixtures, also called extenders. Extenders are materials that reduce the density and/or quantity of cement per unit volume of cement paste or, in the case of the oil well industry, of cement slurry.

The most usual solution to lighten oil well cement slurries is to increase the water-to-cement ratio, since the density of the water is a third of that of cement. Nevertheless, increasing the water content causes other problems such as fluid loss 
and lost circulation. Fluid loss is the leakage of the cement slurry liquid phase into the formation, resulting from high slurry segregation. Lost circulation is the total or partial loss of the cement slurry into the formation. Both problems are controlled by using extenders, since these additives can reduce segregation and increase the yield point of the cement slurry. In addition, using extenders also allows reducing of the quantity of cement per unit volume.

Usually, extenders are divided into three groups according to the way they decrease the density of the cement slurry: low-density materials, gas, and water extenders. In the next section low-density materials and water extenders will be described. Gas extenders, used to obtain foamed cement, exceed the scope of this chapter.

\subsubsection{Low-density materials}

Low-density materials consist of low-weight additions (in the oil well industry also called additives) that can be added by replacing a cement fraction. Usually, the water-to-cement ratio increases since the water-to-solids ratio is maintained constant. Since replacement solids have lower specific weight than cement, the density of slurries decreases. Examples of this group are HGMSs, expanded perlite $\left(30-150 \mathrm{~kg} / \mathrm{m}^{3}\right)$, gilsonite $\left(1070 \mathrm{~kg} / \mathrm{m}^{3}\right)$, and other pozzolanic materials.

To obtain expanded perlite, a siliceous volcanic glass is heat-processed. This glass can expand by a factor of $4-20$ when heated rapidly up to $760^{\circ} \mathrm{C}-980^{\circ} \mathrm{C}$. As a result, a porous particle with entrained air is obtained. Unexpanded perlite has a bulk density of approximately $1100 \mathrm{~kg} / \mathrm{m}^{3}$, but, when expanded it can reach a bulk density as low as $30-150 \mathrm{~kg} / \mathrm{m}^{3}$. Expanded perlite also segregates from the cement slurry due to its low density, therefore it is usually incorporated with a thickening agent, such as bentonite, to prevent this. Expanded perlite is also used in the construction industry because it is an excellent thermal and sound insulator. Lanzón and García Ruiz [38] studied its application in render mortars and found that by adding expanded perlite, fresh density is reduced, and workability is enhanced. In addition, water retention slightly increased at low dosages (which is important to control water evaporation), due to the water retained within perlite internal voids.

Philippacopoulos and Berndt [39] measured thermal properties on cement samples lightened with perlite which had a specific gravity of 1.72 and compared them with properties of neat cement samples with a specific gravity of 1.98 . They found that the thermal conductivity was slightly lower than that of neat cement samples, the coefficient of thermal expansion was higher, and the thermal diffusivity notoriously decreased. In addition, the thermoelastic response of these cement samples was studied by means of finite element models of an oil well. They found that cement samples modified with perlite presented the lowest thermal stresses.

Anya [26] reported the usage of gilsonite as a low-density extender. Gilsonite is a natural asphaltic material. Its low density $\left(1070 \mathrm{~kg} / \mathrm{m}^{3}\right)$ helps to obtain a lightweight cement slurry. Densities as low as $1440 \mathrm{~kg} / \mathrm{m}^{3}$ can be achieved without the aid of high quantities of water. Although it is a lightweight material, gilsonite is nonporous: along with its impermeability, it prevents premature slurry dehydration [40]. When it is used at high concentrations, a viscosity modifier admixture is 
needed to control particle segregation. It can be used in oil well cement slurries but should be avoided in wellbores with high temperatures, as gilsonite particles begin to fuse above $115^{\circ} \mathrm{C}$. William et al. [40] studied gilsonite as a self-healing cement (SHC) additive in a lightweight cement slurry. The self-healing ability would enable the cement sheath to repair microcracks and prevent hydrocarbon migration through the cement-casing and cement-formation interfaces. SHC slurries act as regular cement slurries do, but in addition they can expand when exposed to hydrocarbons, thus sealing microcracks. William et al. [40] worked with cement slurries with a density of $1580 \mathrm{~kg} / \mathrm{m}^{3}$ and different dosages of gilsonite. They found porosity decreased as the concentration of gilsonite increased, both in exposed and unexposed samples to $\mathrm{CH}_{4}$ environments. Nevertheless, the decrease was higher in exposed samples.

Pozzolanic materials, in addition to supplementary cementitious materials, are the most used extenders of the cement slurries in the oil well cement industry. They have lower density than nonhydrated cement and can decrease the hydration heat and permeability of the slurry. They also enhance the resistance to alkali-silica reaction and reduce the susceptibility to acid attack by decreasing the calcium hydroxide content. As examples of pozzolanic materials, fly ash, silica fume, and diatomaceous earth (DE) are described below.

Fly ash is the residue of the combustion of powdered mineral coal. It consists mostly of solid spheres with a particle size that varies from 1 to $100 \mu \mathrm{m}$. The bulk density of noncompacted fly ash ranges from 540 to $860 \mathrm{~kg} / \mathrm{m}^{3}$, while with closepacked storage or vibration it can reach $1120-1500 \mathrm{~kg} / \mathrm{m}^{3}$ [41]. Elmrabet et al. [42] added different dosages of fly ash to ordinary Portland cement. They observed a reduction in the water demand with the increase in fly ash content. They also obtained significant delays in initial and final set of the samples with fly ash. They attributed this result to the reaction of $\mathrm{SiO}_{2}$ present in fly ash. The same reason was given by the authors to explain both the slower early strength development and the lower measured hydration heat as the dosage of fly ash was increased.

Another pozzolanic material is silica fume, also known as microsilica, which is a by-product of the manufacture of silicon or ferrosilicon alloy. The bulk density of the densified silica fume goes from 130 to $430 \mathrm{~kg} / \mathrm{m}^{3}$. Silica fume has a spherical shape, as fly ash, and is extremely fine, with an average particle diameter of about $0.1 \mu \mathrm{m}$. It is used to develop high-strength concrete and high impermeability oil well cement slurries. Its addition reduces bleeding and enhances short-term strength development [41]. Between 5\% and $10 \%$ by weight of cement of silica fume is generally used. Higher dosages are used to improve mechanical performance but undesired effects, such as mixing difficulty and increasing water demand, become more pronounced. These effects where studied by Burroughs et al. [43] and it was concluded that the higher the dosage of silica fume is, the thicker the cement slurry becomes. Furthermore, they observed that this effect was stronger when the specific area of silica fume increased, probably due to a thinner layer of water between particles. In addition, the different specific surface areas affected differently the rheology of the cement slurry. Wang et al. [44] subjected silica fume to a sonication treatment before adding it to the cement slurry and compared the results with a 
slurry with nonsonicated silica fume. They observed that, after sonication, the slurry became less thin, presumably because silica fume agglomerates were broken during sonication, leading to a better distribution of the particles and to a higher specific surface area. They also attributed these reasons to the higher compressive strength obtained.

DE, also called diatomite, is a natural pozzolan. Its main components are opal and amorphous hydrated silica, containing more than $10 \%$ water. Its chemical composition varies depending on the extraction site. To be used as an extender, it is essential that the fineness of the material is similar to that of cement. It has a large surface area and high water demand [45]. Its average particle density can vary from 1200 to $2500 \mathrm{~kg} / \mathrm{m}^{3}$ and its porosity value from $50 \%$ to $70 \%$. Fragoulis et al. [46] studied diatomite rocks from two different extraction sites and found differences in their compositions. However, when adding both ground diatomite rocks to ordinary Portland cement, they found similar effects in their performance. In this work, the water demand of all cements with diatomite was higher than that of the neat cement, and the late compressive strength of most cements was improved with the addition of diatomite. Kastis et al. [47] studied the effects of different percentages (from $0 \%$ to $35 \%$ ) of replacement of cement with diatomaceous rocks which contained mainly $\mathrm{CaCO}_{3}$ and amorphous silica. They found that samples with up to $10 \%$ diatomite developed the same compressive strength as those of neat cement, but a higher water demand was observed with increasing diatomite content.

\subsubsection{Water extenders}

Water extenders allow adding more water to the cement slurry and, therefore, the unit volume of slurry per bag of cement increases (that is why they are called extenders) and its density decreases. When a high quantity of water is added to the slurry, the water-to-solids ratio increases, and the slurry becomes extremely fluid. The presence of a large quantity of water in a slurry generates excessive free water, solids settling, segregation, high permeability, slow strength development, and reduced compressive strength. To prevent these undesired effects from happening, extenders are needed.

The most common of these additives is bentonite, which is used to prevent solids separation, to reduce free water and fluid loss, and to increase the slurry yield point. Bentonite is a clay composed mostly of sodium montmorillonite, that expands when in contact with water. This expansion increments the viscosity, gel strength, and the ability to keep solids suspended in the cement slurry [45]. Bentonite can absorb about $5.3 \%$ of water for every $1 \%$ by weight of cement added, so slurry stability and water retention can be maintained with high water-to-cement ratios. A cement slurry with bentonite can achieve a density as low as $1400 \mathrm{~kg} / \mathrm{m}^{3}$; nevertheless, the low density impacts on the compressive strength [26]. Fig. 16.9 illustrates the effect of bentonite addition on cement compressive strength.

A water extender as effective as bentonite is sodium metasilicate. This consists of a white soluble powder produced by fusing silica with sodium carbonate at high temperatures. Slurry densities of $1400 \mathrm{~kg} / \mathrm{m}^{3}$ can be achieved with $4 \%$ sodium 


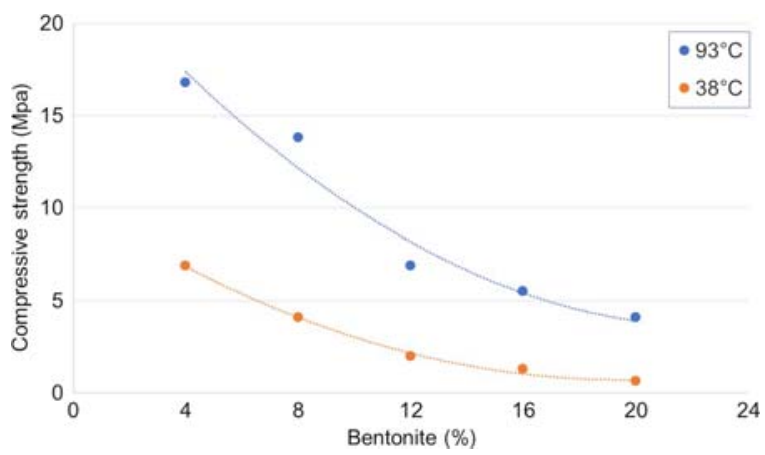

Figure 16.9 Effect of bentonite on the compressive strength of the lightweight cement slurry.

Source: Adapted from E. Nelson, D. Guillot, Well Cementing, Schlumberger, 2008 [48].

metasilicate [26]. The silicates react with the lime in the cement or with calcium chloride, forming a calcium silicate gel, which provides enough viscosity to allow larger water-to-solids ratios without excessive bleeding. This process is different to that exhibited by bentonite extenders that absorb water. Some disadvantages of sodium metasilicates are that they can only be used up to a temperature of $90^{\circ} \mathrm{C}$ and that it tends to reduce the effectiveness of other additives, in particular retarders and agents that prevent fluid loss [45].

Expanded vermiculite is also used as a water extender for cement slurries. It is a magnesium-hydrated silicate with aluminum and iron that expands 8-30 times its size when heated. It has a lamellar structure with air in between that gives the material low density and low thermal conductivity. It is also resistant to high temperatures and to exposure to acids [49]. Gomes da Silva Araujo Filho et al. [49] studied the addition of expanded vermiculite to lightweight oil well cement slurries with high water-to-cement ratios. The density of expanded vermiculite was $730 \mathrm{~kg} / \mathrm{m}^{3}$ and the lightweight cement slurry achieved a density as low as $1500 \mathrm{~kg} / \mathrm{m}^{3}$. To thicken the slurry, they added colloidal silicon that improved cohesion between vermiculite and cement particles. They obtained the highest compressive strength with the highest dosages of vermiculite. In addition, they observed vertical homogeneity and no free water, contrary to what is expected in high water-to-cement ratio slurries. In another work, Minaev et al. [50] observed smaller volumetric shrinkage in lightweight cement slurries containing vermiculite and stated that it was due to the water absorption of expanded vermiculite, since water replaces the air contained between its lamellas. They also reported that increasing dosages of vermiculite resulted in lower density and flowability, reduced thickening times, decreased flexural strength, and higher dehydration. They studied different concentrations of vermiculite with different water-to-solids ratios and showed that a cement slurry with a density of $1480 \mathrm{~kg} / \mathrm{m}^{3}$ could be satisfactorily achieved with $12.5 \%$ vermiculite and 0.8 water-to-solids ratio.

Water extenders can also be water-soluble polymers, which increase the viscosity of the slurry, allowing higher water-to-cement ratios. Among these are cellulose 
ethers (CEs), which are cellulose derivatives. Cellulose is a biopolymer. It is the major constituent of wood and most natural fibers and can also be produced by tunicates (sea animals), some algae species and bacteria, amoebae, and fungi. Some of the cellulose derivatives most used in oil well cement slurries are hydroxyethyl cellulose, methylethylhydroxy cellulose, and carboxymethyl hydroxyethyl cellulose.

Hydroxyethyl cellulose works as a fluid-loss control agent, that allows use of high water-to-cement ratios. Its ability to perform as such is achieved under diverse salinity conditions and under temperatures of up to $150^{\circ} \mathrm{C}$. Carboxymethyl hydroxyethyl cellulose also works as a fluid-loss control agent, inducing, in addition, a setting delay on the cement slurry [51]. Cellulose derivatives have the capacity of thickening the cement slurry, which is convenient when a high water-to-cement ratio is used. Moreover, its water retention ability can prevent fluid loss and segregation, which are common problems in slurries with high water-to-cement ratios, and it can also reduce cement slurry filtration to porous substrates.

In addition to cellulose derivatives, other cellulose products are used, such as micro- and nanocellulose fibers. Natural cellulose macrofibers consist of smaller entities with higher mechanical properties, which can be extracted under proper conditions. Nanocellulose from natural fibers can be extracted by chemical proceedings, like acid hydrolysis used to obtain cellulose nanocrystals (CNCs), or by mechanical treatments. Mechanical treatments make use of elevated shear forces that disintegrate the fibers to obtain cellulose nanofibers (CNFs) [52].

Several papers have been published about cellulose in the form of micro- and nanofibers, and their influence in cement slurry rheology was highlighted. It was observed that shear stress is increased with an increase in the content of CNF in cement matrix. Also, with an increment of the addition, yield stress (defined as the shear stress necessary to start the flow of the slurry) was increased and the slurry exhibited a larger shear thinning effect [53]. These fibers contribute not only to the gain of viscosity but also to the strength development, especially of the flexural modulus, as several research works have shown [53,54].

However, the use of natural fibers is limited in cement-based materials because cellulose fibers contain components that suffer a degradation in the alkaline ambient of the cement paste (lignin, hemicellulose, and amorphous cellulose), which causes fragilization of the fiber. Herein lies the growing interest in other sources of $\mathrm{CNFs}$, such as bacterial nanocellulose (BNC). This is produced by species of bacteria (Komagataeibacter xylinus) through fermentation of low-molecular-weight glucose. BNC has a chemical composition identical to vegetal cellulose, but is purely crystalline and does not contain lignin or hemicellulose.

Martin et al. [55] studied the effect of BNC in oil well cement slurries. With an addition of $0.1 \%$ BNC by weight of cement they obtained an increment in the yield stress of $2000 \%$, which shows the strong influence of BNC on the viscosity of the slurry. They also obtained a drastic decrease in the free fluid percentage of the slurries with $\mathrm{BNC}$, which is an important water retention capacity. Finally, they found an increment of $16 \%$ and $19 \%$ in compressive strength with the addition of $0.1 \%$ and $0.2 \%$ of $\mathrm{BNC}$, respectively, compared to samples without any addition. 


\subsection{Outlook and future trends}

In this chapter, different techniques for lightening cement-based material were studied and reviewed. It is remarkable the great amount of research available regarding this subject, especially when it comes to low-weight aggregates and extenders. The authors have narrowed down the research to three main techniques. These consisted of using EPS, a synthetic lightweight/low-strength aggregate, HGMSs, a synthetic lightweight/high-strength addition, and some of the extenders used to lighten oil well cement slurries. After this wide research it can be concluded that EPS used as concrete aggregate is effective for producing a lightweight material that shows insulating properties. Its incorporation to the mix, however, needs to be done in careful proportion with the other materials present in the mix so that a homogeneous concrete is achieved. Reducing the water-to-cement ratio or incorporating high specific-area admixtures or viscosity-modifying agents are effective ways to create a nonsegregating EPS concrete; however, along these measures, a verification of workability must be assessed in order to obtain a material that can actually be cast and compacted. Reaching an equilibrium between both acceptable cohesion and consistency will lead to a reduction in the compaction energy needed during casting of concrete, which in turn will lead to a reduction in segregation caused during this process.

Deciding which property is to be enhanced will also determine the composition of the mix. Depending on the degree of strength required, a partial or full replacement of stone aggregates by EPS should be made. For a given EPS replacement, reducing the water-to-cement ratio, incorporating pozzolanic admixtures and lowering air content will lead to greater strength values. The opposite actions will lead to a concrete with reduced thermal conductivity, which is beneficial in terms of insulating properties.

HGMSs are newer and mainly used in the oil well industry. Nevertheless, researches have demonstrated that there is a plausible application of HGMSs as an innovating insulation agent for different types of materials. Composites with HGMSs have outstanding thermal conductivity behavior in addition to their low density. When studying the mechanical properties of these materials, it can be outlined that it is not severely affected as when their densities are reduced using regular lightweight additions. When using HGMSs, the selection criteria is key in the composite design, since no clear laws govern their behavior and there are not many researches in this field. Despite this, given the low density and high crush strength of this material, it is expected that there will be an increase in its application for lightweight cement-based materials.

Regarding extenders, their numbers are enormous and it is safe to say that the best for each application is the one that is closer to the construction site. It could be any pozzolanic material, natural expanded material, or additives that allows controlling the free fluids and segregation when increasing the water-to-cement ratio. Special attention should be taken with the strength loss, which varies with the material chosen as an extender, being extreme in some cases and acceptable in others. 


\section{References}

[1] D.J. Cook, Lightweight concrete using expanded polysterene, Constr. Rev. (1972) 53.

[2] E. García-Alcocel, V. Ferrándiz-Mas, Caracterización física y mecánica de morteros de cemento Pórtland fabricados con adición de partículas de poliestireno expandido (EPS), Mater. Constr. 62 (308) (2012) 547-566.

[3] K.G. Babu, D.S. Babu, Performance of fly ash concretes containing lightweight EPS aggregates, Cem. Concr. Compos. 26 (1) (2004) 605-611.

[4] C. Li, L. Miao, Q. You, S. Hu, H. Fang, Effects of viscosity modifying admixture (VMA) on workability and compressive strength of structural EPS concrete, Constr. Build. Mater. 175 (1) (2018) 342-350.

[5] R. Demirboga, A. Kan, Thermal conductivity and shrinkage properties of modified waste polystyrene, Constr. Build. Mater. 35 (1) (2012) 730-734.

[6] R. Sri Ravindrarajah, A.J. Tuck, Properties of hardened concrete containing treated expanded polysterene beads, Ceme. Concr.te Compos. 16 (1) (1994) 273-277.

[7] A. Kan, R. Demirboga, Effect of cement and EPS beads ratios on compressive strength and density of lightweight concrete, Ind. J. Eng. Mater. 14 (1) (2007) 158-162.

[8] B. Chen, N. Liu, Experimental study of the influence of EPS particle size on the mechanical properties of EPS lightweight concrete, Constr. Build. Mater. 68 (1) (2014) 227-232.

[9] D.S. Babu, K.G. Babu, W. Tiong-Huan, Effect of polystyrene aggregate size on strength and moisture migration characteristics of lightweight concrete, Cem. Concr. Compos. 28 (6) (2006) 520-527.

[10] A. Sadrmomtazi, J. Sobhani, M.A. Mirgozar, M. Najimi, Properties of multi-strength grade EPS concrete containing silica fume and rice husk ash, Constr. Build. Mater. 35 (1) (2012) 211-219.

[11] S.G. Park, D.H. Chisholm, Polystyrene Aggregate Concrete, Building Research Association of New Zealand, Judgeford, 1999.

[12] A. Schackow, C. Effting, M.V. Folgueras, S. Güths, G.A. Mendes, Mechanical and thermal properties of lightweight concretes with vermiculite and EPS using airentraining agent, Constr. Build. Mater. 57 (1) (2014) 190-197.

[13] R. Madandoust, M.M. Ranjbar, S. Mousavi, An investigation on the fresh properties of self-compacted lightweight concrete containing expanded polystyrene, Constr. Build. Mater. 25 (1) (2011) 3721-3731.

[14] Y. Xu, L. Jiang, J. Liu, Y. Zhang, J. Xu, G. He, Experimental study and modeling on effective thermal conductivity of EPS lightweight concrete, J. Therm. Sci. Technol. 11 (2) (2016) $1-13$.

[15] C. Cui, Q. Huang, D. Li, C. Quan, H. Li, Stress-strain relationship in axial compression for EPS concrete, Constr. Build. Mater. 105 (1) (2016) 377-383.

[16] A. Kaya, F. Kar, Properties of concrete containing waste expanded polystyrene and natural resin, Constr. Build. Mater. 105 (1) (2016) 572-578.

[17] F. Giurich, T.M. Piqué, Consideraciones para el diseño de hormigones livianos con EPS, in: Proceedings of Congreso de Jóvenes Investigadores en Materiales. Buenos Aires, Argentina, 2017.

[18] F. Giurich, T.M. Piqué, Estudio de la trabajabilidad del hormigón liviano con adición de nanosílice, in: Proceedings of Congreso de la Asosiación Argentina de Tecnología del Hormigón. Olavarría, Argentina, 2018.

[19] M. Ranjbar, Y.S. Mousavi, Strength and durability assessment of self-compacted lightweight concrete containing expanded polystyrene, Mater. Struct. 48 (4) (2013) 1001-1011. 
[20] P.K. Mehta, P.J.M. Monteiro, Concrete Microstructure, Properties, and Materials, McGraw-Hill, 2006.

[21] B. Lothenbach, K. Scrivener, R.D. Hooton, Supplementary cementitious materials, Cem. Concr. Res. 41 (1) (2011) 1244-1256.

[22] B. Chen, J. Liu, Experimental application of mineral admixtures in lightweight concrete with high strength and workability, Constr. Build. Mater. 22 (1) (2008) 1108-1113.

[23] P. Aggarwal, R. Singh, Y. Aggarwal, Use of nano-silica in cement based materials-a review, Cogent Eng. 2 (2015) 1078018.

[24] F. Giurich, Diseño de paneles livianos prefabricados con nanotecnología (Graduate theses of Univesidad de Buenos Aires), Buenos Aires, Argentina, 2019.

[25] Q.L. Yu, P. Spiesz, H.J.H. Brouwers, Ultra-lightweight concrete: conceptual design and performance evaluation, Cem. Concr. Compos. 61 (1) (2015) 18-28.

[26] A. Anya, Lightweight and ultra-lightweight cements for well-cementing-a review, in: Proceedings of SPE Western Regional Meeting SPE-190079-MS, Garden Grove, CA, USA, April 22-26, 2018.

[27] M. Lanzón Torres, P.A. García Ruiz, Lightweight pozzolanic materials used in mortars: evaluation of their influence, Cem. Concr. Compos. 31 (1) (2009) 114-119.

[28] L.C. Herrera-Ramírez, M. Cano, R. Guzman de Villoria, Low thermal and high electrical conductivity in hollow glass microspheres covered with carbon nanofiber-polymer composites, Compos. Sci. Technol. 151 (1) (2017) 211-218.

[29] H. Yang, H. Jiang, D. Xie, C. Wan, H. Pan, S. Jiang, Mechanical, thermal and fire performance of an inorganic-organic insulation material composed of hollow glass microspheres and phenolic resin, J. Colloid Interf. Sci. 530 (2018) 163-170.

[30] S. Shahiron, A. Eeydzah, M.N. Khairiyah, R.H. Nurul Izzati Raihan, S.B. Nur Amira, Potential of hollow glass microsphere as cement replacement for lightweight foam concrete on thermal insulation performance. MATEC Web Conf. 103 (01014), 2017.

[31] D. Oreshkin, V. Semenov, T. Rozocskaya, Properties of light-weight extruded concrete with hollow glass microspheres, Procedia Eng. 153 (2016) 638-643.

[32] J. Gong, Z. Duan, K. Sun, M. Xiao, Waterproof properties of thermal insulation mortar containing vitrified microsphere, Constr. Build. Mater. 123 (1) (2016) 274-280.

[33] R.C. Smith, C.A. Powers, T.A. Dobkins, A new ultra-lightweight cement with super strength, J. Petrol. Eng. 32 (8) (1980) 1438-1444.

[34] F.J. Mavares, A.D. Pertuz, Diseño de un sistema cementante para pozos utilizados en anclaje de plataformas de producción en aguas profundas. caso: Rio de Janeiro, Brasil. Revista de la Facultad de Ingeniería U.C.V. 28 (1) (2013) 73-82.

[35] M.N. Abdullah, D. Bedford, S.R. Wong, H.S. Yap, Prehydrating high-strength microspheres in lightweight cement slurry creates value for offshore Malaysian operator, in: Proceedings of SPE Asia Pacific Oil and Gas Conference and Exhibition SPE-165796MS. Jakarta, Indonesia, October 22-24, 2013.

[36] C. Mata, A. Calubayan, Use of hollow glass spheres in lightweight cements-selection criteria, in: Proceeding of Engineers Asia Pacific Oil and Gas Conference and Exhibition SPE-182399-MS, Perth, Australia, October 25-27, 2016.

[37] H.I. AlBahrani, V. Wagle, A.S. Al-Yami, An overview of experimental studies examining the reliability of hollow glass spheres as a density reduction agent in oil field applications, in: Proceedings of SPE Middle East Oil \& Gas Show and Conference SPE183681-MS, Manama, Kingdom of Bahrain, March 6-9, 2017.

[38] M. Lanzón, P.A. García Ruiz, Lightweight cement mortars: advantages and inconveniences of expanded perlite and its influence on fresh and hardened state and durability, Constr. Build. Mater. 22 (8) (2008) 1798-1806. 
[39] A. Philippacopoulos, M. Berndt, Mechanical response and characterization of well cements. Society of petroleum engineers, in: Proceedings of SPE Annual Technical Conference and Exhibition, September 29-October 2, San Antonio, TX, 2002.

[40] B. William, V. Daniel, M. Radonjic, 2019. Nature's solution to wellbore gas-leakage: gilsonite, in: Proceeding of the 53rd U.S. Rock Mechanics/Geomechanics Symposium, June 23-26, New York, NY, 2019.

[41] S. Kosmatka, B. Kerkhoff, W. Panarese, Design and Control of Concrete Mixtures, Portland Cement Association, 2002.

[42] R. Elmrabet, A. El Harfi, M. El Youbi, Study of properties of fly ash cements, Mater. Today Proc. 13 (3) (2019) 850-856.

[43] J. Burroughs, J. Weiss, J. Haddock, Influence of high volumes of silica fume on the rheological behavior of oil well cement pastes, Constr. Build. Mater. 203 (1) (2019) 401-407.

[44] X. Wang, J. Huang, S. Dai, B. Ma, H. Tan, Q. Jiang, Effect of silica fume particle dispersion and distribution on the performance of cementicious materials: a theoretical analysis of optimal sonication treatment time, Constr. Build. Mater. 212 (1) (2019) $549-560$.

[45] M. Rojas, G. Quercia, K.A. Gorrín, K.C. Gorrin, A. Del Toro, N. Vera, Mecanismos de acción de los aditivos utilizados en cementación de pozos, in: Conferencia sobre materiales cementantes para pozos petroleros, Caracas, Venezuela (USB/MT6511), 2004.

[46] D. Fragoulis, M. Stamatakis, D. Papageorgiou, E. Chaniotakis, The physical and mechanical properties of composite cements manufactured with calcareous and clayey Greek diatomite mixtures, Cem. Concr. Compos. 27 (2) (2005) 205-209.

[47] D. Kastis, G. Kakali, S. Tsivilis, M. Stamatakis, Properties and hydration of blended cements with calcareous diatomite, Cem. Concr. Res. 36 (10) (2006) 1821-1826.

[48] E. Nelson, D. Guillot, Well Cementing, Schlumberger, 2008.

[49] R. Gomes da Silva Araujo Filho, J.C. Oliveira Freitas, M.A. Freitas Meloa, R. Martins Braga, Lightweight oil well cement slurry modified with vermiculite and colloidal silicon, Constr. Build. Mater. 166 (1) (2018) 908-915.

[50] K. Minaev, V. Gorbenko, O. Ulyanova, Lightweight cement slurries based on vermiculite, IOP Conf. Ser.: Earth Environ. Sci. 21 (1) (2014) 012034-012039.

[51] A. Vázquez, T. Pique, Biobased additives in oil well cement, in: S. Goyanes, N. D’Accorso (Eds.), Industrial Applications of Renewable Biomass Products, Springer, 2017, pp. 179-198.

[52] C. Gómez Hoyos, R. Zuluaga, P. Gañán, T.M. Pique, A. Vazquez, Cellulose nanofibrils extracted from fique fibers as bio-based cement additive, J. Clean. Prod. 235 (1) (2019) $1540-1548$.

[53] X. Sun, Q. Wu, J. Zhang, Y. Qing, Y. Wu, Rheology, curing temperature and mechanical performance of oil well cement: combined effect of cellulose nanofibers and graphene nano-platelets, Mater. Des. 114 (1) (2017) 92-101.

[54] O. Onuaguluchi, D. Panesar, M. Sain, Properties of nanofibre reinforced cement composites, Constr. Build. Mater. 63 (1) (2014) 119-124.

[55] C.M. Martin, I. Zapata Ferrero, P. Cerrutti, A. Vázquez, D. Manzanal, T.M. Piqué, Oil well cement modified with bacterial nanocellulose, in: M. Taha (Ed.), International Congress on Polymers in Concrete (ICPIC 2018), Springer, Cham, 2018. ICPIC 2018. 